\title{
A Study on the Style Investment of Equity Funds*
}

\author{
Eunyoung Cho, Deputy Research Fellow, National Pension Research Institute \\ Juil Ban**, Associate Professor, Sangmyung University
}

\begin{abstract}
$<$ Abstract $>$
We classify "fund style" by the fund name and conduct a portfolio-based style analysis. The main results are as follows. First, the proportion of value-style and dividend-style funds is very high compared to other style types in active funds. Second, managers tend not to adhere strictly to the fund style classified by the fund name. Interestingly, the smaller the fund size, the weaker the style characteristics. This result suggests that the management industry neglects small funds and does not fulfill its fiduciary duty. Third, we find that the persistency of the growth style is far behind the value style, and both winner and loser styles have the lowest persistency among all styles. Fourth, timing abilities for market factor, size factor, and value factor are not observed in general, but the timing ability for momentum factor is significantly observed in the active fund group. Fifth, we define artificial fund styles with consistent style investment strategy and compare those with the actual fund styles. We find that the risk of artificial types is generally lower than that of actual types and that several artificial types dominate real types due to higher returns and smaller risks.
\end{abstract}

Keywords: Style Analysis; Portfolio-Based Style; Style Persistence; Style Timing; Fund JEL Classification: G10, G11, G18

* The authors thank Zeroin for providing fund data for this study. We expanded and developed some contents of the research report (Cho et al., 2020) of the National Pension Research Institute, "A study on Style Investment: Implication for the Active External Management of the National Pension Fund," which was prepared by Eunyoung Cho and Juil Ban as the main researchers. The content of the study is irrelevant to the official position of the National Pension Research Institute and is the personal opinion of the authors.

** Corresponding Author. Address: College of Business and Economics, Sangmyung University, 20 Honggimun 2-gil, Jongno-gu, Seoul, Korea, 03016; E-mail: ban9415@smu.ac.kr; Tel: +82-2-781-7586; Fax: +82-2-2287-0059.

Received: October 31, 2020; Revised: February 14, 2021; Accepted: March 8, 2021 


\title{
주식형 펀드의 스타일 투자 실태에 관한 연구 ${ }^{*}$
}

\author{
조 은 영 (국민연금연구원 부연구위원) \\ 반 주 일 (상명대학교 부교수)**
}

\begin{abstract}
이 연구는 펀드명칭이 표방하는 투자 스타일에 따라 스타일 유형을 분류하고 포트폴리오 내역을 기반으로 스타일 분석을 수행하였다. 주요결과는 다음과 같다. 전체시장은 패시브 펀드 중심으로 재편되고 있으며, 액티브 펀드에서는 가치형과 배당형 쏠림 현상이 존재하는 가운데, 펀드명칭에서 표방하는 스타일이 철저히 준수되지 않는 경향을 보였다. 흥미롭게도 펀드규모가 작을수록 스타일 특성이 약해졌고, 펀드규모 그룹 간 스타일 차이는 통계적으로 강한 유의성을 나타냈다. 운용업계가 소규모펀드를 소홀히 취급하면서 신인 의무(fiduciary duty)를 다하지 않음을 시사한다. 스타일 지속성을 검증한 결과 가치주 스타일에 비해 성장주 스타일의 지속성이 뒤쳐지고, 승자주 및 패자주 스타일은 모든 스타일 중에서 지속성이 가장 낮았다. 스타일 타이밍 능력의 존재여부를 검증한 결과 시장요인, 규모요인, 가치요인에 대한 타이밍 능력은 시장 전반에서 관찰되지 않으며, 모멘텀요인에 대한 타이밍 능력은 액티브 펀드 전체집합에서 유의하게 관찰 되었다. 일관된 스타일 투자전략을 구사하는 가상유형을 정의하여 실제유형과 비교할 경우, 가상유형의 위험이 전반적으로 낮았으며, 수익률 또한 우수하여 실제유형을 지배하는 경우가 관찰되었다.
\end{abstract}

핵심 단어 : 스타일 분석, 포트폴리오 기반 스타일, 스타일 지속성, 스타일 타이밍, 펀드

JEL 분류기호: G10, G11, G18

* 연구에 필요한 펀드데이터를 제공해주신 (주)케이지제로인의 관계자 여러분께 감사드립니다. 이 연구는 조은영과 반주일이 참여하여 작성된 국민연금연구원의 연구보고서(Cho et al., 2020), '국민연금 국내주식 액티브 위탁운용 및 국내 공모펀드 운용유형 설정과 성과에 대한 연구'의 일부 내용을 확대 발전시킨 논문입니다. 연구의 내용은 국민연금연구원의 공식 입장과 무관하며 저자들의 개인적인 견해임을 밝힙니다.

** 연락담당 저자. 주소: 서울특별시 종로구 홍지문 2 길 20 상명대학교 경영경제대학 글로벌경영학과, 03016; E-mail: ban9415@smu.ac.kr; Tel: 02-781-7586; Fax: 02-2287-0059. 


\section{1. 서론}

스타일 투자란 주식들의 고유한 속성을 파악하여 특정한 스타일 유형으로 구분하고 스타일 유형 단위에서 주식을 매매하는 행위를 일컫는다. 예를 들어, 주식을 중소형주/ 대형주, 가치주/성장주, 고배당주, 각종 테마주(IT주, 헬스케어주, 삼성그룹주, 4차 산업혁명 관련주 등), 사회적책임투자(SRI) 관련주 등으로 구분하여 포트폴리오를 구성하는 것이다. 기관투자자 및 개인투자자 모두에게 스타일 투자가 유용한 이유는 크게 두 가지로 요약된다 (Barberis and Shleifer, 2003). 첫째, 시장에 상장된 수천 개의 주식을 몇 개의 스타일로 분류 하여 선택의 문제를 단순하게 해주며, 투자자자들로 하여금 방대한 양의 정보를 상당히 효율적으로 처리하게 해준다는 점이다. 둘째, 각 스타일 유형별로 비교집단(peer group)이 자동적으로 생성되므로 머니 매니저(money manager)의 성과를 평가하기가 쉽다는 점이다. 스타일 투자의 개념은 해외에서 업계나 학계를 막론하고 널리 활용되고 있다.

업계에서 가장 잘 알려진 활용사례는 모닝스타의 스타일 박스(Style Box)이다. 스타일 박스는 가로와 세로 각 3 칸씩 총 9 칸의 격자모양으로 구성되며, 가로축에는 가치형(Value), 혼합형(Blend), 성장형(Growth)을 표시하고, 세로축에는 대형(Large), 중형(Mid), 소형(Small)을 표시하여, 특정 포트폴리오가 어느 칸에 해당하는지 시각화 해주는 도구이다. 이러한 도구를 통해 투자자는 자신의 포트폴리오의 특성을 쉽게 파악할 수 있으며, 다양한 스타일 유형에 투자함으로써 분산된 포트폴리오를 구성할 수 있다.

학계에서는 스타일 투자와 관련하여 규모요인(size factor)과 가치요인(value factor)이 잘 알려져 있다. Fama and French(1993)는, 규모요인과 가치요인이 시장요인(market factor)에 더해진 3요인 모형(3-factor model)이 포트폴리오 수익률 변동의 90\% 정도를 설명한다는 결과를 제시한다. 여기서, 규모요인은 소형주 스타일과 대형주 스타일 간의 수익률 차이를, 가치요인은 가치주 스타일과 성장주 스타일 간의 수익률 차이로 정의된다. Carhart(1997)는 Jegadeesh and Titman(1993)에 의해 제시되었던 모멘텀 효과를 반영 하기 위에 3요인 모형에 모멘텀요인(momentum factor)을 추가한 4요인 모형(4-factor model)을 사용하였다. 모멘텀요인은 과거성과가 우수했던 승자주(winner) 스타일과 과거 성과가 저조했던 패자주(loser) 스타일 간의 수익률 차이로 정의된다.

한편, 스타일 투자는 자산운용 과정에서 운용지침을 체계적으로 준수하고 신인의무를 다해야 하는 공적 연기금에서 더욱 유용하여 점차 인기를 얻고 있으며, 스타일 유형 구분이 좀 더 세분화되는 추세를 보이고 있다. 국민연금의 경우, 국내주식에 대한 위탁운용은 2010년 말을 기준으로 순수주식형, 장기투자형, 중소형주형, 사회책임투자형(SRI), 액티브퀀트형의 5 개의 유형으로 구분되었으나, 이후에 대형주형, 가치형, 배당주형이 추가되어 2018년 말 기준으로는 총 8 개의 스타일 유형이 존재하고 있다. 또한 각 유형별로 별도의 벤치마크가 할당되며, 벤치마크에 기반하여 성과를 평가 받게 된다.

그러나, 우리나라에서 스타일 투자의 개념은 주식투자와 관련된 시장 전반에서 체계적으로 
이용되지 못하는 경향이 존재한다. 주가지수를 산출하는 한국거래소는 시가총액 규모에 따른 지수를 산출하고 있으나 아직까지 가치주 지수, 성장주 지수 등 스타일 투자에 기반이 될 지수들을 제공하지 않고 있다. 대표적인 펀드평가사 (주케이지제로인은 주식형 펀드를 총 6개(일반주식, 중소형주식, 배당주식, 테마주식, KOSPI200인덱스, 기타인덱스) 유형으로 분류하는데, ${ }^{1)}$ 펀드명칭에서 가치, 성장스타일을 표방하는 다수의 펀드들을 스타일 특색이 없는 일반주식 유형으로 분류하고 있으며, 일부 펀드들은 중소형주식, 배당주식 유형으로 분류하는 등 스타일 유형 분류체계에 현실성이 없는 실정이다.

이 연구는 우리나라 주식형 공모펀드를 대상으로 스타일 투자 실태를 파악하는 것을 목표로 스타일 분석(Style Analysis)을 수행하고자 한다. 스타일 분석은 펀드의 스타일을 식별하고, 특정 스타일 유형 펀드들의 성과특성을 파악하는 것으로 정의할 수 있다. 스타일을 분석 하는 방법론은 크게 수익률기반 스타일 분석(RBSA, Return-based style analysis)과 포트폴리오 기반 스타일 분석(PBSA, Portfolio-Based Style Analysis) 2가지로 구분된다.

먼저, RBSA는 Sharpe(1992)에 의해 제시되었으며, 펀드의 수익률만을 이용하고, 포트 폴리오 내역을 이용하지 않는다는 분석의 용이성 측면에서 많이 사용되어 왔다. RBSA를 이용한 국내 연구로는 Kang and Lee(2010), Kwon and Song(2010), Kho et al.(2011), Lee and Jeon(2012), Yoo and Kim(2012), Kim and Yoo(2013), Ha(2015) 등이 있다. $\mathrm{RBSA}$ 는 여러 가지 벤치마크 요인에 대한 요인계수(factor loadings)를 추정하여 펀드의 스타일을 간접적으로 추론하기 때문에, RBSA 방법론을 통해 유의미한 결과를 도출하려면 충분한 시계열이 필요하다. 그러나, 우리나라의 경우 RBSA를 적용하기에는 펀드데이터가 구축되기 시작한 역사가 짧고, 개별펀드의 수명 자체도 짧은 편이다. ${ }^{2)}$ 또한 RBSA는 시계열 데이터를 이용한 간접 추론 방법론이므로, 운용 스타일의 변동이 있을 경우 이를 빠르게 인식하기 어렵다는 단점이 존재한다. 이와 관련하여 Chan et al.(2002)은 RBSA를 통해 과거수익률을 이용하여 스타일을 추론하는 경우 그러한 스타일이 현재의 실제 스타일과 현저하게 다를 수 있음을 지적하였다.

이러한 문제점을 보완하는 방법론이 PBSA라고 할 수 있다. $\mathrm{PBSA}$ 는 특정시점의 포트 폴리오 내역을 직접 관찰함으로써 펀드의 스타일을 비교적 정확히 파악하고, 포트폴리오 내역 변동을 추적하면 스타일의 변동 또한 즉각적으로 파악할 수 있다. Chan et al.(2002)는 수익률을 이용하여 추정된 요인계수를 이용하는 RBSA에 비해, 포트폴리오정보를 이용하는 PBSA가 펀드 수익률을 보다 정확하게 예측한다고 하였다. 물론, PBSA 방법론을 이용하게 되면 처리해야 할 데이터의 양이 급격히 증가하고 분석이 복잡하다는 단점이 존재한다.

1) 편드시장 초창기(1990년대 후반 2000년대 초반)에서 사용되던 분류를 그대로 사용하고 있는 것으로 보인다.

2) Investment Company Institute(2019)에 따르면 우리나라는 조세피난처인 룩셈부르크를 제외하고 세계에서 펀드수가 가장 많은 나라이다. 다른 나라에 비해 펀드수명이 짧은 원인으로 지나치게 많은 펀드들이 출현하고 빠르게 사라진다는 점이 지목된다. 
한국증권학회지 제 50 권 2호 (2021)

그럼에도 불구하고, 분기별로 포트폴리오 내역이 제공되는 미국시장의 펀드 데이터에 비해 우리나라 펀드 데이터는 월 단위로 포트폴리오 내역이 제공되어 데이터 질이 상당히 우수 하다는 점, 국내 선행연구에서 PBSA가 시도되지 않은 점을 감안한다면 PBSA 방법론이 우리나라 주식형 펀드의 스타일을 분석하기에 유용할 것으로 판단된다.

이에 따라, 이 연구에서는 PBSA 방법론을 채택하였으며 2009년 1월부터 2018년 12월까지 10 년간의 우리나라 주식형 공모펀드 데이터를 사용하여 아래와 같은 분석을 수행하였다. 첫째, 현실성 있는 스타일 유형 분류를 위해 액티브 펀드 명칭에 특정 단어가 포함되는지 여부에 따라 총 8개(중소형, 대형, 가치형, 성장형, 배당형, 사회적책임투자형, 테마형, 일반 주식형) 유형으로 분류하였다. 패시브 펀드에 대해서는 $\mathrm{ETF}$ 여부, 코스피200지수 추종여부에 따라 4개 유형(코스피 $200 \mathrm{ETF}$ 형, 기타지수ETF형, 코스피200인덱스형, 기타지수인덱스형) 으로 분류하였다. 둘째, 월별 포트폴리오 정보를 이용하여 총 7 가지의 스타일(종목수, 종목 집중도, 산업집중도, 시가총액, 장부가-시장가 비율, 배당수익률, 모멘텀)을 측정하고, 스타일 측정값을 상대순위(0\%부터 $100 \%$ 사이의 percentile ranking)로 변환하였다. 셋째, 특정 유형의 스타일 상대순위와 시장점유율을 비교함으로써 펀드가 표방하고 있는 스타일을 준수하고 있는지 살펴보았다. 또한, Ban and Choe(2013)가 제시한 방치가설(Negligence Hypothesis)의 관점에서 펀드매니저가 소규모 펀드를 소홀하게 운용하는지 파악하기 위해 펀드규모가 클수록 스타일 특색이 뚜렷하고, 작을수록 특색없이 운용되고 있는지 검증하였다. 넷째, 특정 투자 스타일이 꾸준히 지속되는지 또는 빈번히 변경되는지 Carhart(1997)의 순위분할표(contingency in ranking table) 방법을 차용하여 분석하였다. 다섯째, 스타일 유형별로 적절한 타이밍을 포착하는 스타일 타이밍 능력(style timing ability)이 있는지 4요인 모형을 기반으로 분석하였다. 구체적으로 요인 수익률이 비음 $(0$ 또는 +$)$ 일 경우에 이를 추가적인 타이밍 요인으로 사용하여 타이밍 요인에 대한 계수(factor loading)가 통계적으로 유의한 양수(+)값을 나타내는지 검증하는 방법이다. 여섯째, 7 가지 스타일 상대순위를 기반 으로 스타일 특성이 가장 뚜렷한 1분위(하위 10\%) 및 10분위(상위 10\%) 그룹을 각각 가상의 스타일 유형으로 정의하고, 가상유형을 실제유형과 다양한 방법으로 비교함으로써 현재의 스타일 투자 실태가 개선될 여지가 있는지 파악해 보았다.

이 연구의 서론 이후는 다음과 같이 구성하였다. 제 2장에서는 데이터 및 연구방법론을 설명하고, 제 3장에서는 실증분석 결과를 제시하였다. 제 4장에서는 이 연구의 주요결과를 요약하고 시사점 및 제언을 제시하였다.

\section{2. 데이터 및 연구방법론}

\section{1 데이터}

이 연구는 펀드평가회사 (주)케이지제로인의 국내 주식형 공모펀드 데이터를 이용하였으며, 


\section{A Study on the Style Investment of Equity Funds}

분석기간은 2009년 1월부터 2018년 12월까지이다. ${ }^{3)}$ (주케이지제로인이 제공한 데이터는 크게 기본정보, 일별정보, 월말시점 포트폴리오 정보로 구성된다. 기본정보에서는 펀드코드, 설정일 및 해지일, 제로인유형, 모펀드 및 자펀드 구분, 프라이머리펀드(primary fund) 및 클래스펀드(class fund) 구분, 개방형 및 폐쇄형 구분, 추가형 및 단위형 구분, 총보수, 선취 수수료 및 후취수수료를 사용하였다. 일별정보에서는 펀드코드, 기준일, 순자산, 수익률을 사용하되, 일별정보는 공시일 기준으로 제공되어 실제 운용일 기준과 1 영업일의 시차가 발생하기 때문에 정확한 분석을 위하여 공시일을 운용일로 보정하는 작업 후에 사용하였다. 월말시점 펀드 포트폴리오 정보에서는 종목코드, 보유종목 시가평가액을 사용하였다. 4 요인 모형 구성 및 스타일 측정을 위해 주식수익률, 시가총액, 자기자본, 우선주자본금, 배당수익률, 산업분류를 (주)에프엔가이드의 DataGuide 프로그램을 이용하여 추출한 후 사용하였다. 국고 채권 3 개월물의 시가평가 기준수익률을 금융투자협회 채권정보센터에서 추출하여 무위험 수익률의 대용치로 사용하였다.

\section{2 표본구성}

중도인출이 불가능한 폐쇄형펀드와 추가납입이 불가능한 단위형펀드는 제외하였다. 모자형 펀드의 경우 자펀드만 사용하고 모펀드는 제외하였다. 멀티클래스 펀드의 경우 클래스 펀드는 제외하고 프라이머리 펀드를 사용하였다. 프라이머리 펀드의 순수익률, 보수, 수수료는 프라이머리펀드와 클래스펀드 간 매칭을 통해 클래스 펀드들의 값을 가치가중(value-weight) 평균하여 계산하였다. 프라이머리 펀드의 순자산은 클래스 펀드의 개별 순자산을 합산하여 계산하였다. 표본기간동안 평균 순자산이 10 억 원 미만인 소규모 펀드는 정상적으로 운용되기 어렵다고 판단하여 제외하였다. 펀드의 인큐베이션(incubation) 문제 ${ }^{4)}$ 및 현금유입이 지속 적으로 발생하는 신생펀드 효과를 완화하기 위해 펀드가 설정된 후로부터 1 년이 경과되지 않은 펀드의 수익률 데이터는 사용하지 않았다. 또한, 펀드가 해지되기 직전에는 일반적으로 펀드 순자산이 매우 작아서 수익률 데이터에 이상치(outlier)가 존재할 가능성이 있기 때문에

3) 분석기간을 2009년부터 설정한 이유는 다음과 같다. 표본선정기준을 통과한 펀드들에 대하여 스타일 분류를 시도했을 때, 2006년 이전의 경우 전체 액티브 펀드 중에서 특색있는 스타일 분류가 가능한 펀드 개수는 $20 \%$ 를 밑돌았고, $80 \%$ 이상이 일반주식형으로 분류되어 스타일분류 작업이 의미를 가지기 어렵다고 판단하였다. 또한, 2006 2007년의 경우 특정유형의 펀드수가 지나치게 작게 (중소형 5 6개, SRI유형 1 2개, KOSPI200ETF형 2개 등) 나타났다. 2008년의 경우 글로벌금융 위기 인하여 포트폴리오 정보에 다른 년도와 다르게 이질성이 존재할 가능성 및 이 연구에서 참고하고 있는 펀드규모효과(fund size effect)와 관련하여 Kim et al.(2019)은 2009년을 전후하여 양(+)의 펀드 규모효과가 사라진다는 사실을 발견한 점 등을 감안하여 저자들은 2009년부터 분석기간으로 삼는 것이 적절하다고 판단하였다.

4) 펀드 설정 후 초기성과가 좋았던 펀드만을 일정기간 경과 후 투자자들에게 판매함으로써, 초기성과가 다른 기간의 성과에 비해 부풀려지는 문제이다. 더 자세한 설명에 대해서는 Evans(2010)와 Fama and French(2010)를 참조할 것. 
한국증권학회지 제 50 권 2호 (2021)

펀드 해지 전 6 개월 간은 분석대상에서 제외하였다. 펀드의 포트폴리오 정보가 월별로 제공된다는 점, 연구에서 사용한 요인모형 또한 월별수익률을 기반으로 하는 점을 감안하여 펀드의 일별 수익률을 월별 수익률로 변환하여 사용하였다. 펀드 수익률 데이터에는 수수료가 반영되지 않기 때문에 수수료가 있는 펀드의 수익률이 수수료가 없는 펀드에 비해 부풀려지는 문제가 존재한다. 이러한 문제를 완화하기 위해 Morey(2003)는 펀드수수료를 투자자의 평균투자기간동안 감모상각(amortizing)시켜 비용화하는 방법을 제안하였다. 이 연구에서는 Morey(2003)의 방법론을 우리나라 상황에 맞도록 응용한 Ban(2015), Ban et al.(2016)과 같이 펀드수수료를 30 개월 동안 감모상각하여 수익률에서 차감하였다.

\section{3 펀드 스타일 유형 분류}

실무적으로 주식형 펀드의 스타일 유형을 분류하는 방법론은 크게 둘로 나뉜다. 첫째, 펀드가 표방하는 정보를 가지고 분류하는 방법이며, 펀드명칭, 약관, 투자설명서, 마케팅 자료 등의 정보를 이용하게 된다. 우리나라의 대표적인 펀드평가회사 (주케이지제로인이 이 방법을 사용하고 있다. ${ }^{5)}$ 둘째, 펀드가 실제로 어떤 스타일의 주식에 투자하고 있는지에 기반하여 분류하는 방법이며, 포트폴리오 정보를 이용하게 된다. 모닝스타의 스타일 박스가 이 방법을 이용하고 있다. ${ }^{6)}$

이 연구에서는 펀드가 표방하고 있는 스타일이 실제로 준수되고 있는지 살펴보는 것을 목표로 하기에 우선 첫 번째 방법을 이용하여 펀드의 스타일 유형을 분류하는 것이 타당 하다. 손쉬운 방법으로 (주)케이지제로인의 분류체계를 그대로 가져다 사용하는 것을 생각 해 볼 수 있겠으나, 서론에서 설명한 바와 같이 가치, 성장과 같은 기본적인 스타일조차 구분하지 못할 정도로 현실성이 없는 실정이다. 대안적인 방법으로서 가장 단순하면서도 객관적인 정보라고 할 수 있는 펀드명칭을 이용하여 스타일을 분류한다. 먼저, 스타일 분석의 주요한 대상이 되는 액티브 펀드에 대해서는 연구자가 펀드명칭에 포함된 특정 단어를 검색하여 8개 유형(중소형, 대형, 가치형, 성장형, 배당형, 사회적책임투자형, 테마형, 일반 주식형)으로 분류하였다. 다음으로, 액티브펀드에 대비하여 비교기준이 되는 패시브 펀드에 대해서는 펀드명칭에 따른 분류를 하지 않고 $\mathrm{ETF}$ 여부, 코스피200 지수 추종 여부에 따라 4 개 유형(코스피200ETF형, 기타지수ETF형, 코스피200인덱스형, 기타지수인덱스형)으로 간단한 분류를 하였다. 각 유형에 대한 설명 및 구체적인 분류기준은 <표 $1>$ 에 제시하였다.

5) (주케이지제로인이 운영하는 펀드닥터(www.funddoctor.co.kr)에서 제공하는 유형분류 및 펀드평가 방법론을 살펴보면 약관 및 상품설명서(투자설명서)에 기초하여 유형을 분류하고 있음을 알 수 있다.

6) 모닝스타(www.morningstar.com)에서 제공하는 스타일박스 방법론에 대한 factsheet을 살펴보면 주식형펀드가 실제로 보유하고 종목에 기초하여 유형을 분류하고 있음을 알 수 있다. 


\section{〈표 1〉펀드의 스타일 유형 분류기준}

연구자가 펀드의 스타일 유형을 분류한 기준을 나타낸다. Active는 액티브펀드 전체를, Passive는 패시브펀드 전체를 의미한다. 액티브 펀드는 펀드명칭에 특정 단어가 포함되는지 여부를 통해 스타일 유형을 분류하였고, 2개 이상의 유형(예를 들면 배당, 성장이라는 단어를 동시에 포함하는 경우)에 중복하여 분류되는 경우가 발생하였다. 패시브 펀드는 제로인의 분류기준을 토대로 하여 ETF여부에 따라 분류하였고 중복하여 분류되지 않았다.

\begin{tabular}{|c|c|c|c|}
\hline & 스타일 유형 & 투자 스타일 & 분류기준 \\
\hline \multirow[t]{7}{*}{ Active } & $\begin{array}{l}\text { Small } \\
\text { Big }\end{array}$ & $\begin{array}{l}\text { 중소형 } \\
\text { 대형 }\end{array}$ & $\begin{array}{l}\text { - 소형, 스몰, 리틀, 작은, 중기, 강소라는 단어 } \\
\text { - 대형, 빅이라는 단어 } \\
\text { * 특정 운용사 펀드의 고유명사로 사용되는 Big\&Safe } \\
\text { 에는 대형주의 의미가 없으므로 제외하였음. } \\
\text { *리틀빅스타에는 빅이라는 단어가 포함되지만 소형주에 } \\
\text { 투자하는 펀드이므로 제외하였음. }\end{array}$ \\
\hline & Value & 가치형 & $\begin{array}{l}\text { - 가치, 밸류라는 단어 } \\
\text { * 진주찾기라는 단어를 포함하는 펀드는 가치주투자를 } \\
\text { 표방하므로 추가적으로 포함시킴 }\end{array}$ \\
\hline & Growth & 성장형 & $\begin{array}{l}\text { - 성장, 그로스라는 단어 } \\
\text { * 지속성장 또는 지속가능성장이라는 단어는 sustainable } \\
\text { development를 의미하여 제외시키고 SRI형으로 } \\
\text { 분류 }\end{array}$ \\
\hline & Dividend & 배당형 & - 배당이라는 단어 \\
\hline & SRI & $\begin{array}{l}\text { 사회적 } \\
\text { 책임투자형 }\end{array}$ & $\begin{array}{l}\text { - SRI, ESG, 녹색, 그린, 지배구조, 책임, 에코, 지속가능, } \\
\text { 지속성장이라는 단어 } \\
\text { * 꿈에그린, 에버그린이라는 단어는 펀드명칭의 고유 } \\
\text { 명사처럼 사용될 뿐 SRI투자와 관계가 없어 제외 } \\
\text { 하였음. }\end{array}$ \\
\hline & Theme & 테마형 & $\begin{array}{l}\text { - 테마, 산업, 코스닥이라는 단어 } \\
\text { - 특정 섹터(소비재, 컨슈머, 소재, 금융, IT 등) 또는 } \\
\text { 특정 산업(바이오, 헬스케어, 테크, 레저, 미디어, } \\
\text { 엔터테인먼트 등)과 관계되는 단어 } \\
\text { - 정치·경제·사회·문화적 시류(4차산업, 통일, 한류, } \\
\text { 웰니스, 스마트, } \mathrm{AI}, \text { 벤처, M\&A, 인플레이션, 장수기업 } \\
\text { 등)와 관계되는 단어 } \\
\text { - 특정 그룹(삼성, LG, GS, SK, 현대, 현대차), 대표그룹, } \\
\text { 5대그룹, } 3 \text { 대그룹 등과 같이 그룹주 투자에 특화한 } \\
\text { 펀드임을 나타내는 단어 }\end{array}$ \\
\hline & Gen & 일반주식형 & - 위의 분류기준에 해당하지 않는 액티브 펀드 \\
\hline \multirow[t]{4}{*}{ Passive } & K200 ETF & $\begin{array}{l}\text { 코스피 } 200 \\
\mathrm{ETF} \text { 형 }\end{array}$ & $\begin{array}{l}\text { - 제로인 유형 'KOSPI200 인덱스'에서 ETF에 해당하는 } \\
\text { 펀드 }\end{array}$ \\
\hline & Other ETF & $\begin{array}{l}\text { 기타지수 } \\
\text { ETF형 }\end{array}$ & $\begin{array}{l}\text { - 제로인 유형 ‘기타 인덱스’에서 ETF에 해당하는 펀드 } \\
\text { * 레버리지, 인버스 상품은 제외하였음. }\end{array}$ \\
\hline & $\begin{array}{l}\text { K200 } \\
\text { Index }\end{array}$ & $\begin{array}{l}\text { 코스피200 } \\
\text { 인 덱스형 }\end{array}$ & $\begin{array}{l}\text { - 제로인 유형 'KOSPI200 인덱스'에서 ETF를 제외한 } \\
\text { 펀드 }\end{array}$ \\
\hline & $\begin{array}{l}\text { Other } \\
\text { Index }\end{array}$ & $\begin{array}{l}\text { 기타지수 } \\
\text { 인 덱스형 }\end{array}$ & $\begin{array}{l}\text { - 제로인 유형 '기타 인덱스'에서 } \mathrm{ETF} \text { 를 제외한 펀드 } \\
\text { * 레버리지, 인버스 상품은 제외하였음. }\end{array}$ \\
\hline
\end{tabular}




\section{4 포트폴리오 기반 스타일 및 스타일 상대순위 측정}

월말 기준 포트폴리오 정보를 이용하여 전통적인 요인모형과 관련되는 스타일인 기업규모 (시가총액), 가치성향(장부가-시장가 비율), 모멘텀(과거수익률) 뿐만 아니라, 실무적으로 널리 사용되는 배당, 학계에서 사용되는 집중도 등 아래와 같은 총 7 가지의 포트폴리오 기반 스타일을 측정한다. 또한, 측정된 포트폴리오 기반 스타일 값을 상대순위(0\%부터 $100 \%$ 사이의 percentile ranking)로 변환한다.

(1) 종목수(NPFO, Number of stocks held in a Portfolio)

포트폴리오 내 주식 종목수로 정의되며, 우선주를 제외하고 보통주 만으로 계산하였다. $\mathrm{NPFO}$ 가 클수록 여러 종목에 분산투자를 하고 있음을 의미한다.

(2) 종목집중도(SCI, Stock Concentration Index)

포트폴리오 내에서 각 종목이 차지하고 있는 비율(weight)을 제곱하여, 그 값을 합산한 허핀달 지수(Herfindahl index)값으로 계산된다. SCI가 클수록 특정종목에 집중하여 투자 함을 의미한다.

(3) 산업집중도(ICI, Industry Concentration Index)

포트폴리오 내에서 10 가지 ${ }^{7)}$ 산업이 차지하는 비율을 제곱하여, 그 값을 합산한 허핀달 지수값으로 계산된다. $\mathrm{ICI}^{8)}$ 가 클수록 특정산업에 집중하여 투자함을 의미한다.

(4) 시가총액(Size)

Pollet and Wilson(2008)이 사용한 방식으로 포트폴리오 내의 각 종목 시가총액을 해당 종목에 대한 편입비율로 가중평균한 값(weighted average market cap of stocks)으로 계산된다. Size가 클수록 대형주에 투자하는 경향이 강함을 의미한다.

(5) 장부가-시장가 비율(이하 BTM, Book to Market)

포트폴리오 내에서 각 종목의 장부가/시장가 비율을 해당종목에 대한 편입비율로 가중 평균한 값(weighted average book-to- market ratio of stocks)으로 계산된다. BTM이 클수록 가치주에 투자하는 경향이 강함을 의미한다.

(6) 배당수익률(이하 DY, Dividend Yield)

포트폴리오 내에서 각 종목의 시가기준 배당수익률(현금배당총액/시가총액)을 해당종목에 대한 편입비율로 가중평균한 값으로 계산된다. DY가 클수록 고배당주에 투자하는 경향이 강함을 의미한다.

7) IT, 경기소비재, 금융, 산업재, 소재, 에너지, 유틸리티, 의료, 통신서비스, 필수소비재.

8) Kacperczyk et al.(2005)이 사용한 산업집중도(ICI)는 각 산업이 포트폴리오 내에서 차지하는 비중 에서 각 산업이 벤치마크 내에서 차지하는 비중을 차감한 후 제곱하고, 이 값들을 합산하므로 상대 적인 산업집중도라고 부를 수 있다. 반면에 이 연구에서 사용한 방법은 절대적인 산업집중도 계산 하는 것이다. 
(7) 모멘텀(이하 MOM, Momentum)

포트폴리오 내에서 각 종목의 직전 1 개월을 제외한 과거 12 개월 수익률을 해당종목 편입비율로 가중평균한 값으로 계산된다. $\mathrm{MOM}$ 이 클수록 승자주에 투자하는 경향이 강함을 의미한다.

\section{5 스타일 준수 실태}

특정유형에 속한 펀드들의 스타일 상대순위 평균값을 산출해 봄으로써 펀드가 표방하고 있는 스타일을 준수하고 있는지 살펴본다. 예컨대, 장부가-시장가 상대순위에서 가가치형은 $100 \%$ 에 가까운 값을, 성장형은 $0 \%$ 에 가까운 값을 나타낸다면 비교적 스타일을 잘 준수 하고 있음을 의미할 것이다. 반대로 가치형, 성장형 모두 $50 \%$ 에 가까운 값을 나타낸다면 펀드명칭이 표방하는 바와는 달리 스타일 특색이 없이 운용된다고 볼 수 있다. 또한, 펀드 규모 ${ }^{9)}$ 에 따라 스타일 준수 정도가 달라지는지 검증한다. Ban and Choe(2013)는 펀드 매니저가 여러 펀드를 동시에 운용하는 상황에서 작은 규모의 펀드를 소홀히 하는 경향이 있다는 방치가설(Negligence Hypothesis)을 제시하였고, 현금보유비중 및 펀드성과를 이용해 실증적으로 뒷받침하고 있다. 펀드규모가 클수록 스타일 특색이 뚜렷하고, 작을수록 특색 없이 운용되고 있다면, 이것 역시 방치가설을 지지하는 결과라고 할 수 있을 것이다.

\section{6 스타일 지속성 검증}

특정 투자 스타일이 꾸준히 지속되는지 빈번히 변경되는지 Carhart(1997)의 순위분할표 (contingency in ranking table) 방법을 차용하여 분석한다. 구체적으로 이번기의 스타일 상대순위를 10 분위 그룹으로 구분한 후, 이번기의 순위(initial ranking)에 따라서 다음기의 순위(subsequent ranking)로 어떻게 변화하는지 조건부 확률(conditional probability)을 도출하는 방식이다.

\section{7 스타일 타이밍 능력 검증}

펀드가 표방하는 스타일이 꾸준히 유지되지 않고 변경되는 경향이 있다면, 펀드는 해당 스타일에 대한 타이밍을 하고 있다고 할 수 있다. 스타일 유형별로 적절한 타이밍을 포착 하는 스타일 타이밍 능력(style timing ability)이 있는지 검증한다. Chan et al.(2002)는 Henriksson and Merton(1981)이 제시한 방법론을 기반으로 3요인 수익률이 비음(0 또는

9) 문헌에서 펀드규모효과(fund size effect)는 펀드규모에 따라 펀드수익률에 차이가 발생하는 현상을 일컫는다. Chen et al.(2004), Pollet and Wilson(2008), Chan et al.(2009) 등의 해외 연구들은 음(-)의 규모효과를 보고하고 있으며, 이러한 효과가 나타나는 원인으로 펀드규모가 커짐에 따라 주식매매 시 유동성충격 또한 커진다는 점을 지목하고 있다. 그러나, 우리나라 펀드시장을 2001년부터 2009 년까지의 기간에 대해서 연구한 Ban and Choe(2013)은 해외시장과 반대되는 양(+)의 규모 효과를 발견하였다. 한편, 2005년부터 2015년까지의 기간에 대해서 연구한 Kim et al.(2019)는 양의 규모효과가 2009년을 전후하여 사라진 것으로 보고한다. 
한국증권학회지 제 50 권 2호 (2021)

+)일 경우에 이를 추가적인 타이밍 요인으로 사용하여 타이밍 요인에 대한 계수가 유의한 양수(+) 값인지를 분석하여 스타일 타이밍 능력이 존재하는지 검증하였다. 이 연구에서는 3 요인에 모멘텀요인을 추가한 4요인 모형을 기반으로 스타일 타이밍 능력이 존재하는지 검증하기로 한다. 시장요인(RMRF), 규모요인(SMB), 가치요인(HML)은 Fama and French (1993)의 방법론을, 모멘텀요인(MOM)은 Carhart(1997)의 방법론을 각각 한국의 유가증권 시장(KOSPI) 및 코스닥시장(KOSDAQ)에 적용하여 계산하였다. $\mathrm{RF}$ 는 무위험수익률을 의미하며 3 개월 만기의 국고채 유통수익률을 1 개월 수익률로 환산하여 사용하였다. RM은 시장수익률을 의미하며 유가증권시장 및 코스닥시장에 상장된 모든 보통주를 대상으로 시가 총액 가중방식으로 계산하였다. 스타일 타이밍 능력을 검증하기 위한 회귀분석모형은 식 (1)과 같다.

$$
\begin{aligned}
R_{k, t}-R_{f, t}= & a_{k}+\beta_{1 k} R M R F_{t}+\beta_{2 k} S M B_{t}+\beta_{3 k} H M L_{t}+\beta_{4 k} M O M_{t}+\beta_{5 k} \max \left(0, R M R F_{t}\right) \\
& +\beta_{6 k} \max \left(0, S M B_{t}\right)+\beta_{7 k} \max \left(0, H M L_{t}\right)+\beta_{8 k} \max \left(0, M O M_{t}\right)+\epsilon_{k, t}
\end{aligned}
$$

위의 식은 펀드가 시장상황에 따라 스타일에 대한 노출도를 조절함을 가정하고 있다. 규모요인을 예로 들어 보자. SMB 수익률이 음수인 경우(소형주 수익률이 대형주보다 낮은 경우) 노출도는 $\beta_{2}$ 가 되며, $\mathrm{SMB}$ 수익률이 양수인 경우(소형주 수익률이 대형주보다 높은 경우) 노출도는 $\beta_{2}+\beta_{6}$ 가 된다. $\beta_{6}$ 가 양수이면서 통계적으로 유의할 때, 펀드가 규모요인에 대한 타이밍 능력을 가지는 것으로 해석된다.

\section{8 펀드 스타일 실제유형 대 가상유형 비교}

포트폴리오 정보를 이용하여 측정한 7가지 스타일 상대순위를 기반으로 스타일 특성이 가장 뚜렷한 1 분위(하위 10\%) 및 10분위(상위 $10 \%$ ) 그룹을 각각 Bottom, Top 그룹으로 구분하고, 새로운 스타일 유형으로 정의하였다. 이러한 유형은 실제로 존재했던 유형(펀드 명칭을 기반으로 구분한 실제 유형)과 대비되는 유형으로써 스타일 특성을 뚜렷하게 유지 하는 일관된 투자전략을 구사하였다면 어떠한 차이가 발생하는지 비교해 볼 수 있는 가상의 펀드 유형이라고 할 수 있다. 실제유형과 가상유형의 비교는 다음과 같은 4 가지 방법으로 수행한다.

첫째, 동일한 스타일 유형에 속하는 펀드들의 수익률을 매월 동일가중 횡단면 평균한 후 연결하여 스타일 유형 수익률 시계열을 구한 후 스타일 유형 간의 상관계수를 계산한다. 분산투자효과를 극대화하려는 투자자라면 이와 같은 유형간 상관계수를 유용하게 활용할 수 있을 것이다. 둘째, 펀드투자자가 부담하는 비용인 보수 및 수수료를 유형별로 계산한다. 유형에 따른 비용특성을 이해함으로써 비용관점에서 투자자에게 유리한 유형을 파악할 수 있을 것이다. 셋째, 펀드 유형별로 4요인 모형을 분석하여 요인계수(factor loadings) 및 순수익률 기준 초과성과(net alpha)를 추정하고, 유형별 보수 및 수수료를 더하여 총수익률 기준 초과성과(gross alpha)를 추정한다. 4요인모형은 식 (1)에서 4 가지 타이밍 요인들 
$\left(\max \left(0, R M R F_{t}\right), \max \left(0, S M B_{t}\right), \max \left(0, H M L_{t}\right), \max \left(0, M O M_{t}\right)\right.$ 을 제거한 것이다. 특정 스타일을 표방하는 펀드들이 실제로 해당 스타일을 추구했는지, 유형별로 위험조정 초과 성과 창출능력에는 어느 정도 차이가 있는지 알 수 있을 것이다. 넷째, 실제유형 및 가상 유형별로 표본기간동안 평균, 표준편차, 샤프지수 등을 계산하고, 위험-수익률 프로파일(riskreturn profile)을 그려본다. 이를 통해 현재의 스타일 투자 실태가 개선될 여지가 있는지 시 사점을 도출해보고자 한다.

\section{3. 실증분석 결과}

\section{1 스타일 유형 현황}

<표 2>의 Panel A는 스타일 유형별 펀드개수를 표본기간 동안 매년 말 기준으로 나타 내었다. 눈에 띄는 점은 대형 유형의 펀드가 1 2개에 불과할 정도로 펀드 시장에서 대형 주에 투자하는 유형이 인기를 얻지 못한다는 것이다. 펀드수가 가장 급격하게 증가한 유형은 기타지수 ETF형이며 2009년 말에 21개였으나 2018년 말에는 140개에 달하고 있다.

Panel B는 각 유형에서 펀드들의 평균 NAV를 보여준다. 전반적인 규모 면에서 액티브 펀드는 감소, 패시브 펀드는 증가 추세를 보이고 있으며, 특히 ETF 유형들의 규모증가가 두드러지게 나타나고 있다. 펀드규모가 가장 큰 유형은 코스피200ETF형으로 2018년 말 기준으로 평균 $\mathrm{NAV}$ 가 1 조 5천억 원을 넘는 대규모 펀드임을 알 수 있다. 액티브 유형 중에서는 가치형, 배당형이 규모가 가장 크다.

Panel C는 각 유형의 총 NAV를 나타내며, Panel D는 총 NAV를 시장점유율로 환산한 값이다. 액티브 펀드들의 인기가 감소하고, 패시브 펀드들이 급격히 성장하였음을 알 수 있다. 또한, 액티브 유형 중에서도 특별한 투자스타일을 표방하지 않는 일반주식형의 점유율 감소가 가장 두드러지게 나타나고 있다. 반면, 스타일 투자를 표방하는 가치형, 배당형, 중소형, 성장형 등은 점유율이 오히려 증가하거나 일정수준으로 유지되고 있음을 알 수 있다. 2018년 말 기준으로 액티브 펀드 중에서 스타일 특색이 없는 일반주식형을 제외하고 인기 있는 스타일 유형은 가치형 $(12.4 \%) \rightarrow$ 배당형 $(10.8 \%) \rightarrow$ 중소형 $(4.9 \%) \rightarrow$ 테마형(4.0\%) $\rightarrow$ 성장형 $(2.6 \%) \rightarrow$ 사회적책임투자형 $(0.4 \%)$ 순서이다. 전반적으로 가치형과 배당형으로의 쏠림 현상이 존재한다. 또한 가치형과 성장형 중에서는 가치형으로, 중소형과 대형 중에서는 중소형으로 인기가 편중되어 있다.

\section{2 스타일 및 스타일 순위 측정 결과}

<표 3>의 Panel A는 월말 기준 포트폴리오 내역을 이용하여 펀드의 스타일을 7가지 기준으로 계산하고 같은 유형 내에서 횡단면 동일가중 평균한 후에 표본기간동안 시계열 


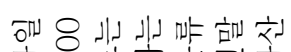

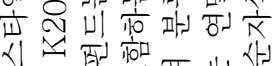

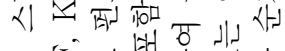

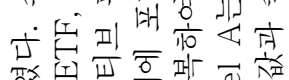

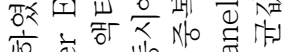
夜

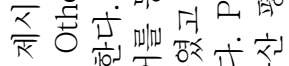

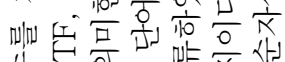

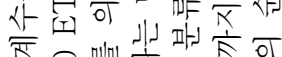

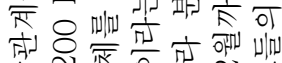

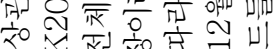

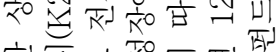

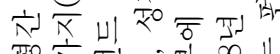

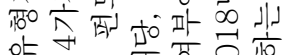
of 겅

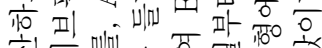

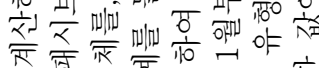

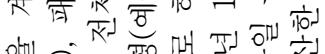
of of

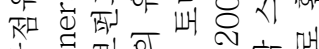

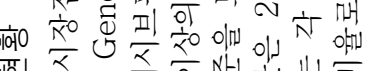

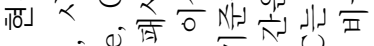

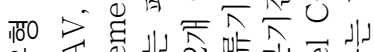

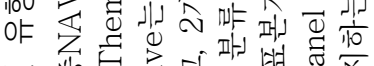

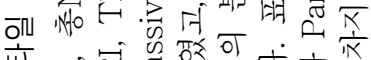

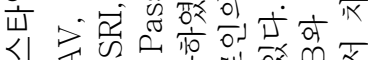

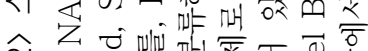

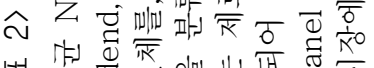

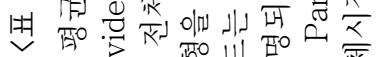

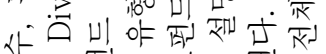

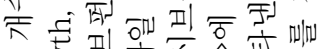

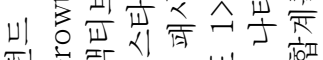
知它敌

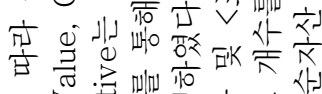

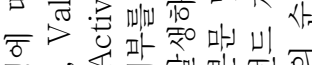

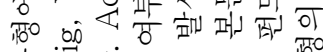

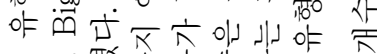

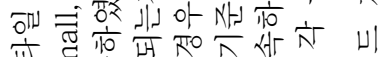

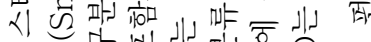

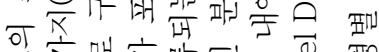

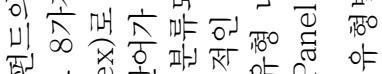

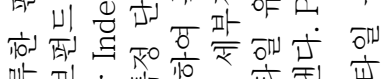

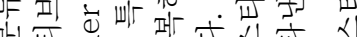

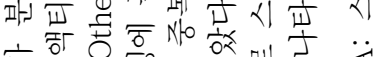

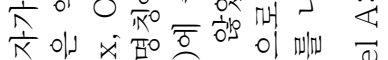

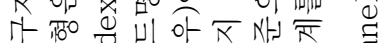

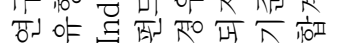

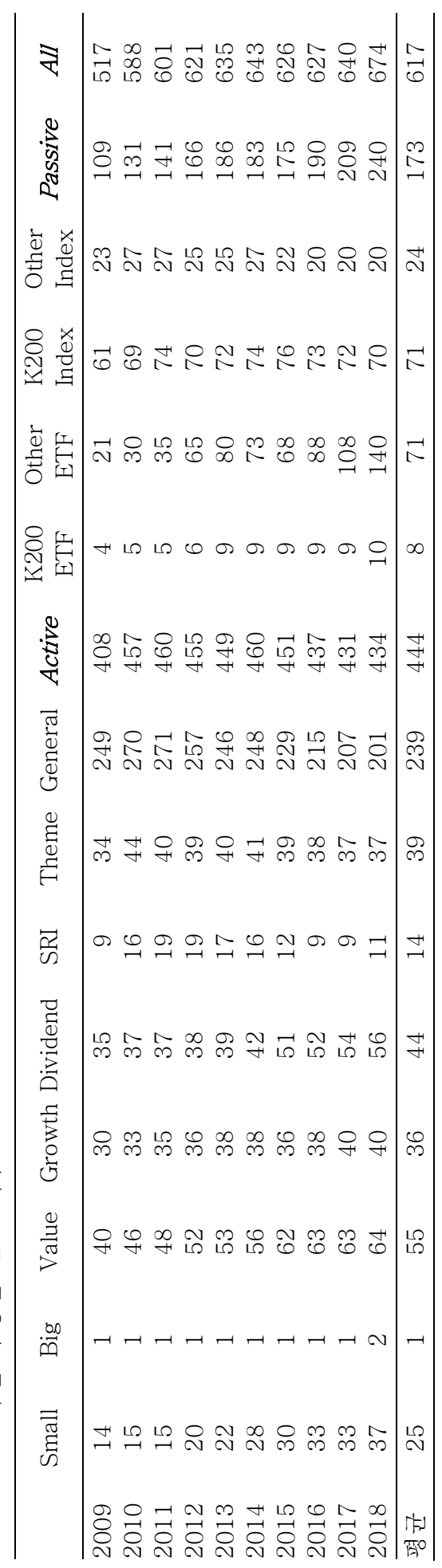



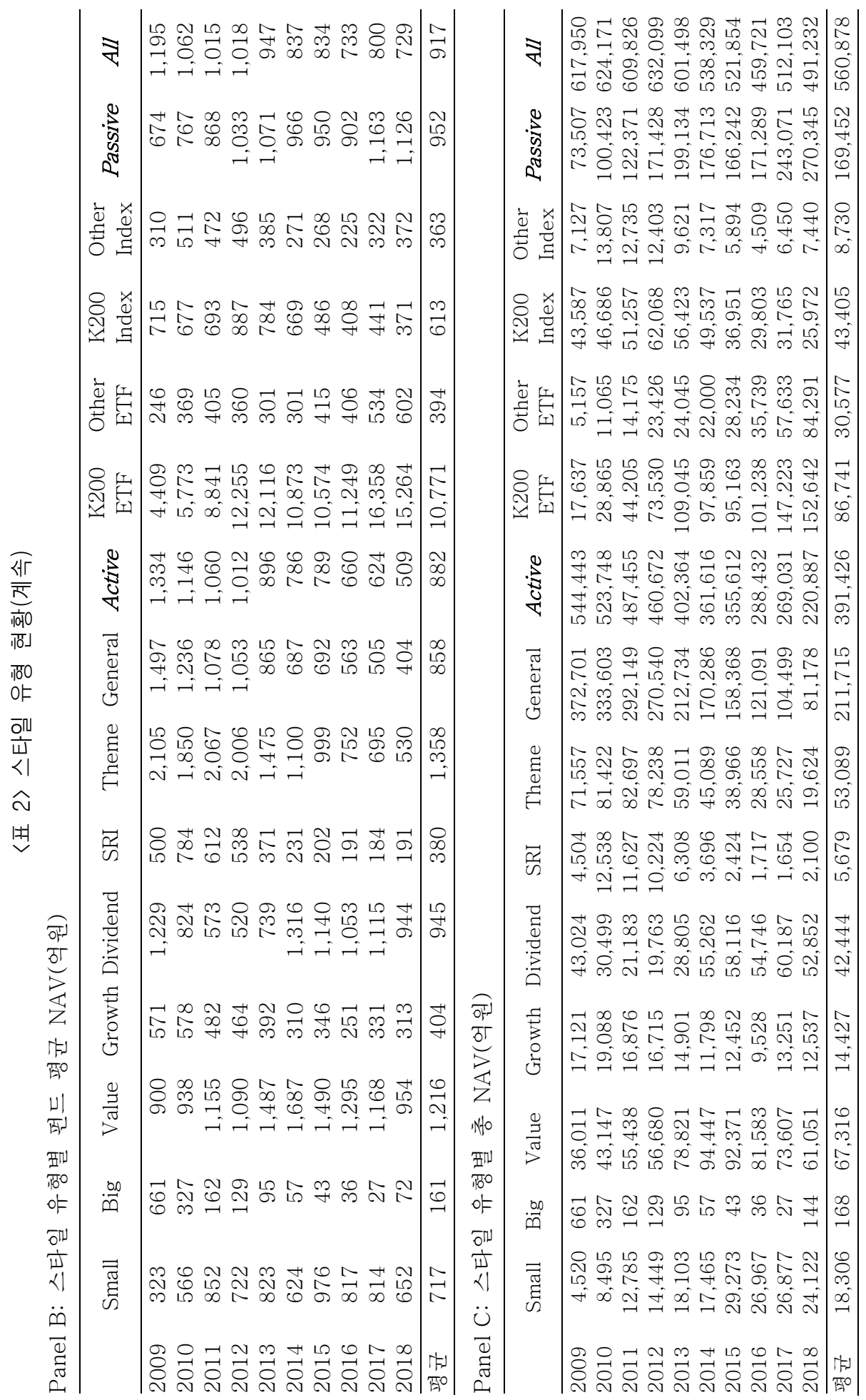


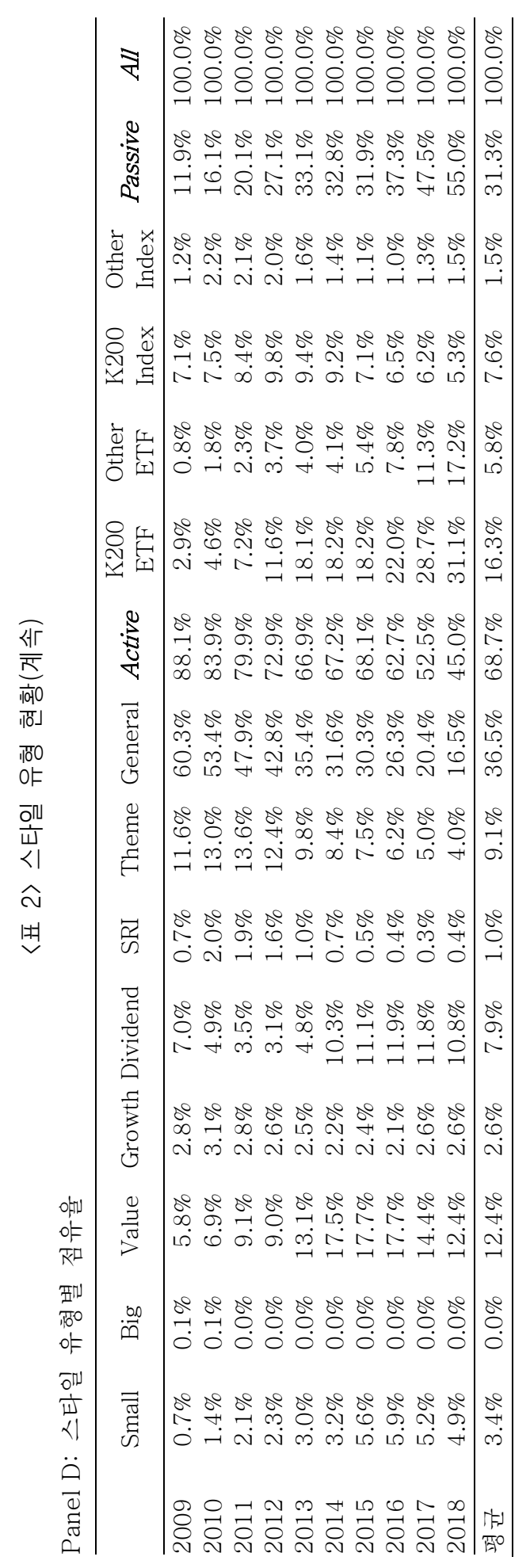


A Study on the Style Investment of Equity Funds

평균한 값을 보여준다. 먼저 종목수(NPFO)는 액티브 펀드 전체에서 60 종목, 패시브 펀드 전체에서 115 종목으로 2 배 가까운 차이가 발생하고 있다. 액티브 펀드 중에서 종목수가 많은 스타일 유형은 중소형(67개), 배당형(66개), 가치형(63개)이며 종목수가 적은 스타일 유형은 테마형(40개), 대형(32개)이다.

종목집중도(SCI)는 액티브 펀드 전체에서 0.046, 패시브 펀드 전체에서 0.071 로 종목 수와는 다른 정보를 내포하고 있음을 알 수 있다. 종목수가 많더라도 특정 종목들에 집중하여 투자

\section{〈표 3〉스타일 측정결과}

매월 말 기준 포트폴리오 정보를 이용하여 펀드의 스타일을 측정하였다. 이렇게 측정한 스타일 값의 크기에 따라 $0 \%$ (스타일 값 작음)부터 $100 \%$ (스타일 값 큼)사이의 백분위 순위(percentile ranking)로 변환시킨 것이 스타일 상대순위이다. 같은 스타일 유형 내에서 스타일 측정값과 스타일 상대순위를 횡단면 동일가중 평균한 후 표본기간동안 시계열 평균한 값을 제시하였다. 스타일 유형은 액티브펀드 8가지(Small, Big, Value, Growth, Dividend, SRI, Theme, General), 패시브펀드 4가지(K200 ETF, Other ETF, K200 Index, Other Index)로 구분하였다. Active는 액티브펀드 전체를, Passive는 패시브펀드 전체를, All은 펀드 전체를 의미한다. 액티브 펀드는 펀드명칭에 특정 단어가 포함되는지 여부를 통해 스타일 유형을 분류하였고, 2 개 이상의 유형(예를 들면 배당, 성장이라는 단어를 동시에 포함하는 경우)에 중복하여 분류되는 경우가 발생하였다. 패시브 펀드는 제로인의 분류기준을 토대로 하여 $\mathrm{ETF}$ 여부에 따라 분류하였고 중복하여 분류되지 않았다. 세부적인 분류기준은 본문 및 <표 1 >에 설명되어 있다. 표본기간은 2009년 1월부터 2018년 12월까지이다. NPFO는 포트폴리오 내에 포함된 보통주 보유 종목 개수이다. SCI는 각 보유종목이 차지하는 비중을 제곱하여 합산한 값이다. ICI는 포트폴리오 내에서 10 가지(IT, 경기소비재, 금융, 산업재, 소재, 에너지, 유틸리티, 의료, 통신서비스, 필수소비재) 산업이 차지하는 비중을 제곱하여 합산한 값이다. Size는 보유종목의 시가총액을 각 종목이 포트폴리오 내에서 차지하는 비중으로 가중하여 평균한 값이다. BTM은 보유종목의 장부가-시장가 비율을 각 종목이 포트폴리오 내에서 차지하는 비중으로 가중하여 평균한 값이다. $\mathrm{MOM}$ 은 보유종목의 과거 12 개월 수익률을 직전 1 개월을 제외하고 측정한 후 각 종목이 포트폴리오 내에서 차지하는 비중으로 가중 하여 평균한 값이다.

Panel A: 스타일 측정값

\begin{tabular}{lccccccc}
\hline \multicolumn{1}{c}{ 스타일 유형 } & $\begin{array}{c}\text { NPFO } \\
\text { (종목) }\end{array}$ & SCI & ICI & $\begin{array}{c}\text { SIZE } \\
\text { (조원) }\end{array}$ & BTM & DY & MOM \\
\hline Small & 66.7 & 0.028 & 0.215 & 11.7 & 0.788 & $1.16 \%$ & $37.65 \%$ \\
Big & 31.7 & 0.084 & 0.198 & 52.5 & 0.800 & $1.24 \%$ & $21.90 \%$ \\
Value & 63.5 & 0.039 & 0.185 & 29.1 & 0.863 & $1.34 \%$ & $21.25 \%$ \\
Growth & 60.6 & 0.043 & 0.193 & 34.9 & 0.771 & $1.13 \%$ & $25.68 \%$ \\
Dividend & 66.2 & 0.036 & 0.164 & 29.2 & 0.880 & $1.68 \%$ & $21.36 \%$ \\
SRI & 56.3 & 0.045 & 0.182 & 38.7 & 0.787 & $1.21 \%$ & $24.93 \%$ \\
Theme & 40.5 & 0.061 & 0.294 & 34.4 & 0.738 & $1.11 \%$ & $20.77 \%$ \\
General & 60.8 & 0.048 & 0.186 & 38.9 & 0.776 & $1.22 \%$ & $23.13 \%$ \\
Active & 59.7 & 0.046 & 0.195 & 34.7 & 0.790 & $1.25 \%$ & $23.38 \%$ \\
\hline K200 ETF & 167.4 & 0.060 & 0.178 & 55.9 & 0.795 & $1.37 \%$ & $15.04 \%$ \\
Other ETF & 47.8 & 0.097 & 0.470 & 23.9 & 0.837 & $1.39 \%$ & $13.57 \%$ \\
K200 Index & 164.8 & 0.063 & 0.181 & 54.1 & 0.804 & $1.38 \%$ & $15.16 \%$ \\
Other Index & 118.8 & 0.050 & 0.180 & 36.2 & 0.861 & $1.50 \%$ & $13.08 \%$ \\
Passive & 114.6 & 0.071 & 0.281 & 38.8 & 0.824 & $1.40 \%$ & $14.10 \%$ \\
\hline All & 74.1 & 0.053 & 0.219 & 35.8 & 0.801 & $1.29 \%$ & $20.96 \%$ \\
\hline
\end{tabular}


한국증권학회지 제 50 권 2호 (2021)

〈표 3〉스타일 측정결과(계속)

Panel B: 스타일 상대순위

\begin{tabular}{lccccccc}
\hline \multicolumn{1}{c}{ 스타일 유형 } & NPFO & HHI & ICI & SIZE & BTM & DY & MOM \\
\hline Small & $54 \%$ & $18 \%$ & $58 \%$ & $15 \%$ & $47 \%$ & $41 \%$ & $79 \%$ \\
Big & $18 \%$ & $87 \%$ & $61 \%$ & $85 \%$ & $54 \%$ & $43 \%$ & $56 \%$ \\
Value & $51 \%$ & $35 \%$ & $46 \%$ & $38 \%$ & $62 \%$ & $56 \%$ & $51 \%$ \\
Growth & $50 \%$ & $40 \%$ & $55 \%$ & $45 \%$ & $46 \%$ & $33 \%$ & $60 \%$ \\
Dividend & $54 \%$ & $30 \%$ & $31 \%$ & $36 \%$ & $63 \%$ & $73 \%$ & $52 \%$ \\
SRI & $44 \%$ & $44 \%$ & $48 \%$ & $50 \%$ & $48 \%$ & $41 \%$ & $61 \%$ \\
Theme & $26 \%$ & $63 \%$ & $73 \%$ & $41 \%$ & $37 \%$ & $34 \%$ & $47 \%$ \\
General & $45 \%$ & $48 \%$ & $47 \%$ & $51 \%$ & $45 \%$ & $42 \%$ & $57 \%$ \\
Active & $46 \%$ & $44 \%$ & $49 \%$ & $45 \%$ & $48 \%$ & $45 \%$ & $56 \%$ \\
K200 ETF & $92 \%$ & $73 \%$ & $41 \%$ & $91 \%$ & $51 \%$ & $68 \%$ & $36 \%$ \\
Other ETF & $26 \%$ & $73 \%$ & $74 \%$ & $37 \%$ & $53 \%$ & $54 \%$ & $33 \%$ \\
K200 Index & $90 \%$ & $67 \%$ & $40 \%$ & $86 \%$ & $55 \%$ & $68 \%$ & $37 \%$ \\
Other Index & $67 \%$ & $48 \%$ & $34 \%$ & $53 \%$ & $64 \%$ & $74 \%$ & $29 \%$ \\
Passive & $64 \%$ & $65 \%$ & $50 \%$ & $63 \%$ & $55 \%$ & $64 \%$ & $33 \%$ \\
\hline All & $50 \%$ & $50 \%$ & $50 \%$ & $50 \%$ & $50 \%$ & $50 \%$ & $50 \%$ \\
\hline
\end{tabular}

한다면, 종목집중도는 오히려 커질 수 있음을 말해준다. 액티브 펀드 중에서 종목집중도가 높은 스타일 유형은 대형(0.084) $\rightarrow$ 테마형(0.061) $\rightarrow$ 일반주식형(0.048) $\rightarrow$ 사회적책임투자형 $(0.045) \rightarrow$ 성장형(0.043) $\rightarrow$ 가치형(0.039) $\rightarrow$ 배당형(0.036) $\rightarrow$ 중소형(0.028) 순서이다.

산업집중도(ICI)는 특정한 산업을 벤치마크로 추종하는 경우가 많은 기타지수ETF형에서 두드러지게 높은 값을 보이고 있으며, 패시브펀드 전체 평균값을 크게 끌어올리고 있다. 기타지수ETF형을 제외하면 액티브와 패시브 간 차이가 크지 않은 것으로 보인다. 액티브 펀드 전체에서 산업집중도가 높은 스타일 유형은 테마형(0.294)이며, 가장 낮은 유형은 배당형(0.164)이다. 테마형이 산업수준에서 가장 집중된 투자를, 배당형은 산업수준에서 가장 분산된 투자를 하고 있음을 말해준다.

포트폴리오에 포함된 종목들의 가중평균 시가총액(Size)은 액티브 펀드 전체에서 34.7 조 원, 패시브 펀드 전체에서 38.8조 원이다. 흥미롭게도 Size 측정치가 가장 큰 유형은 대형이 아니라 코스피200ETF형인데 이는 해당 유형이 시가총액 상위 200개 종목을 추종하도록 운용되는 반면, 대형 유형은 시가총액 상위 200개가 아닌 종목에도 투자하는 방식으로 운용되기 때문인 것으로 풀이된다. Size 측정치가 가장 작은 유형은 중소형으로 평균 11.7 조 원 수준이다.

포트폴리오에 포함된 종목들의 가중평균 장부가-시장가 비율(BTM)은 전체 시장에서 0.801 수준으로 나타난다. 흥미로운 점은 BTM이 가장 높은 유형이 가치형이 아니라 배당형인데, 두 유형의 가치주 속성이 비슷하다는 것을 알 수 있다. 또한 BTM이 가장 낮은 유형이 성장형이 아니라는 점도 주목할 만하다. 성장형의 BTM은 테마형보다 높은 값을 보이고, 표방하는 스타일 특색이 없는 일반주식형과 비슷한 수준이다. 성장형 유형의 펀드들이 펀드명칭에서 표방한 스타일을 철저히 준수하지 않았음을 말해주고 있다. 
포트폴리오에 포함된 종목들의 가중평균 시가 배당수익률(DY)는 전체 시장에서 $1.29 \%$ 수준으로 나타나고 있으며, DY가 가장 높은 유형은 예상대로 배당형(1.68\%)이고, 가장 낮은 유형은 테마형(1.11\%)이다.

모멘텀(MOM)은 포트폴리오 내에서 개별종목의 과거 12 개월 수익률을 직전 1 개월을 제외 하고 측정하여 해당종목 편입비율로 가중평균한 값이다. 전체 시장에서 모멘텀은 $20.96 \%$ 수준인데, 액티브 펀드와 패시브 펀드 유형간에 모멘텀 측정값 차이가 무려 $9.28 \%$ 에 달할 정도로 액티브 펀드가 패시브 펀드에 비해 승자주(winner)를 선호하는 투자전략을 구사하고 있음을 말해준다. 모멘텀이 가장 두드러지는 유형은 중소형(37.65\%)이다. 해당 유형의 성과가 우수하다면 소형주 프리미엄과 승자주 프리미엄이 혼합된 결과임을 시사한다.

Panel B는 앞서 살펴본 스타일 값을 매월 말을 기준으로 전체 시장 내에서 $0 \%$ 부터 $100 \%$ 까지의 상대순위로 환산하고, 같은 유형 내에서 횡단면 동일가중 평균한 후 표본기간 동안 시계열 평균한 값을 보여준다. 스타일 값이 커질수록 상대순위가 커지도록 계산하였다. 중소형의 Size 상대순위를 보면 15\%(예컨대 전체시장에 펀드가 1000개 존재한다고 가정 하면 보유종목의 가중평균시가총액이 작은 순서로 상위 150 등이라는 것을 의미)로써 해당 유형이 대체로 소형주 스타일로 운용되었음을 말해준다. 그러나, <표 2>의 Panel D에서 보았듯이 중소형의 점유율이 표본기간동안 평균적으로 $3.4 \%$ 정도이기 때문에 해당유형이 소형주 스타일을 가장 철저히 준수했다면 중소형의 Size 상대순위는 $3.4 \%$ 이내여야(예컨대 1,000 개 중에 상위 1 등 34 등) 할 것이다. 따라서 Size 상대순위는 더욱 줄어들 여지가 있다. 가치형, 성장형의 BTM 상대순위 $62 \%, 46 \%$ 를 보면 스타일을 준수하지 않는 성향이 더욱 크게 나타난다. 해당유형의 점유율이 평균적으로 각각 $12.4 \%, 2.6 \%$ 수준이기 때문에 스타일을 가장 철저하게 준수하였다면 BTM 상대순위는 각각 $87.6 \%, 2.6 \%$ 와 비슷한 값을 나타낼 것으로 기대할 수 있다. 이러한 성향은 배당형에서도 관찰되고 있다. 배당형의 DY 상대순위는 $73 \%$ 인데, 해당유형의 평균 점유율 $7.9 \%$ 를 고려한다면, 고배당주 스타일을 철저히 준수하지 않았음을 시사한다.

\section{3 펀드규모에 따른 스타일 준수 실태}

펀드규모가 클수록 스타일 특색이 뚜렷하고, 작을수록 특색없이 운용되고 있는지 검증 하기 위해 각 유형내의 펀드들을 펀드규모에 따라 매월 말에 Low(하위 $30 \%$ ), Medium (중간 40\%), High(상위 30\%) 그룹으로 구분하고, 스타일 및 스타일 상대순위를 그룹별로 측정하여 보았다. 이러한 펀드규모 그룹별 차이는 벤치마크 지수를 추종하는 패시브 펀드 보다는 펀드매니저의 재량에 따라 스타일 준수여부를 조절할 수 있는 액티브 펀드에서 두드러질 것으로 예상되어, 액티브 펀드만을 분석하되, 상대순위는 펀드시장 전체에서 산출 하였다. 또한 대형 유형은 제한된 표본수로 인해 그룹화가 불가능하여 제외하였다. <표 4 >의 Panel A와 Panel B는 펀드규모별 스타일 측정값과 스타일 상대순위를 나타낸다. 중소형의 Size, 가치형 및 성장형의 BTM, 배당형의 $\mathrm{DY}$ 측정값과 상대순위를 보면 펀드규모가 커질수록 스타일 특성이 더욱 뚜렷해짐을 알 수 있다. 흥미로운 점은 성장형에서 Low그룹은 
한국증권학회지 제 50 권 2호 (2021)

\section{〈표 4〉액티브펀드의 펀드규모별 스타일 측정결과}

특정 스타일 유형을 펀드 순자산 규모에 따라 Low(하위 30\%), Medium(중간 40\%), High(상위 30\%) 3 그룹으로 구분하였다. 매월 말 기준 포트폴리오 정보를 이용하여 펀드의 스타일을 측정하였다. 이렇게 측정한 스타일 값의 크기에 따라 $0 \%$ (스타일 값 작음)부터 $100 \%$ (스타일 값 큼)사이의 백분위 순위 (percentile ranking)로 변환시킨 것이 스타일 상대순위이다. Panel A와 Panel B는 같은 스타일 유형 및 하위 펀드 규모그룹 내에서 스타일 측정값과 스타일 상대순위를 횡단면 동일가중 평균한 후 표본 기간동안 시계열 평균한 값을 제시하였다. Panel $\mathrm{C}$ 는 펀드규모 그룹간에 스타일 차이가 통계적으로 유의한지 검증한 결과이다. 액티브펀드의 스타일 유형은 펀드명칭에 특정 단어가 포함되는지 여부를 통해 8가지(Small, Big, Value, Growth, Dividend, SRI, Theme, General)로 구분하였고, 2개 이상의 유형(예를 들면 배당, 성장이라는 단어를 동시에 포함하는 경우)에 중복하여 분류되는 경우가 발생하였다. $\mathrm{Big}$ 유형은 펀드 개수가 지나치게 작아 그룹화가 불가능하여 제외하였다. 세부적인 분류기준은 본문 및 <표 1>에 설명되어 있다. Active는 액티브펀드 전체를 의미한다. 표본기간은 2009년 1월부터 2018년 12월까지이다. NPFO는 포트폴리오 내에 포함된 보통주 보유종목 개수이다. SCI는 각 보 유종목이 차지하는 비중을 제곱하여 합산한 값이다. ICI는 포트폴리오 내에서 10가지(IT, 경기소비재, 금융, 산업재, 소재, 에너지, 유틸리티, 의료, 통신서비스, 필수소비재) 산업이 차지하는 비중을 제곱하여 합산한 값이다. Size는 보유종목의 시가총액을 각 종목이 포트폴리오 내에서 차지하는 비중으로 가중하여 평균한 값이다. BTM은 보유종목의 장부가-시장가 비율을 각 종목이 포트폴리오 내에서 차지하는 비중으로 가중하여 평균한 값이다. MOM은 보유종목의 과거 12 개월 수익률을 직전 1 개월을 제외하고 측정한 후 각 종목이 포트폴리오 내에서 차지하는 비중으로 가중하여 평균한 값이다.

Panel A: 펀드규모별 스타일 측정값

\begin{tabular}{|c|c|c|c|c|c|c|c|c|c|}
\hline $\begin{array}{l}\text { 스타일 } \\
\text { 유형 }\end{array}$ & $\begin{array}{c}\text { 펀드규모 } \\
\text { 그룹 }\end{array}$ & $\begin{array}{l}\text { 순자산 } \\
\text { (억원) }\end{array}$ & $\begin{array}{l}\mathrm{NPFO} \\
\text { (종목) }\end{array}$ & HHI & ICI & $\begin{array}{l}\mathrm{SIZE} \\
\text { (조원) }\end{array}$ & BTM & DY & $\mathrm{MOM}$ \\
\hline \multirow[t]{3}{*}{ Small } & Low & 33 & 57.6 & 0.032 & 0.251 & 15.6 & 0.766 & $1.15 \%$ & $38.29 \%$ \\
\hline & Medium & 182 & 61.8 & 0.031 & 0.217 & 14.2 & 0.758 & $1.06 \%$ & $36.95 \%$ \\
\hline & High & 2,118 & 85.0 & 0.023 & 0.185 & 7.1 & 0.824 & $1.29 \%$ & $32.50 \%$ \\
\hline \multirow[t]{3}{*}{ Value } & Low & 20 & 56.9 & 0.043 & 0.189 & 33.8 & 0.821 & $1.28 \%$ & $22.99 \%$ \\
\hline & Medium & 144 & 62.4 & 0.039 & 0.187 & 28.6 & 0.855 & $1.30 \%$ & $22.04 \%$ \\
\hline & High & 3,810 & 82.8 & 0.033 & 0.164 & 23.1 & 0.968 & $1.56 \%$ & $17.33 \%$ \\
\hline \multirow[t]{3}{*}{ Growth } & Low & 29 & 62.9 & 0.040 & 0.196 & 31.9 & 0.785 & $1.11 \%$ & $24.90 \%$ \\
\hline & Medium & 149 & 57.6 & 0.046 & 0.190 & 38.0 & 0.774 & $1.15 \%$ & $25.01 \%$ \\
\hline & High & 1,079 & 61.6 & 0.044 & 0.187 & 35.6 & 0.758 & $1.11 \%$ & $24.74 \%$ \\
\hline \multirow[t]{3}{*}{ Dividend } & Low & 19 & 60.5 & 0.038 & 0.172 & 29.3 & 0.840 & $1.60 \%$ & $21.36 \%$ \\
\hline & Medium & 200 & 62.1 & 0.038 & 0.166 & 29.6 & 0.841 & $1.67 \%$ & $22.55 \%$ \\
\hline & High & 2,787 & 88.8 & 0.033 & 0.147 & 28.2 & 0.992 & $1.88 \%$ & $16.73 \%$ \\
\hline \multirow[t]{3}{*}{ SRI } & Low & 26 & 54.5 & 0.046 & 0.184 & 39.0 & 0.812 & $1.24 \%$ & $24.16 \%$ \\
\hline & Medium & 85 & 59.3 & 0.043 & 0.181 & 36.3 & 0.784 & $1.19 \%$ & $26.65 \%$ \\
\hline & High & 1,105 & 50.4 & 0.051 & 0.183 & 40.5 & 0.752 & $1.24 \%$ & $21.41 \%$ \\
\hline \multirow[t]{3}{*}{ Theme } & Low & 26 & 43.9 & 0.058 & 0.306 & 30.4 & 0.762 & $1.11 \%$ & $22.99 \%$ \\
\hline & Medium & 277 & 39.0 & 0.065 & 0.274 & 39.8 & 0.745 & $1.10 \%$ & $19.23 \%$ \\
\hline & High & 4,193 & 30.6 & 0.071 & 0.268 & 38.2 & 0.698 & $1.11 \%$ & $15.13 \%$ \\
\hline \multirow[t]{3}{*}{ General } & Low & 22 & 61.7 & 0.051 & 0.193 & 38.0 & 0.790 & $1.24 \%$ & $23.13 \%$ \\
\hline & Medium & 167 & 61.7 & 0.047 & 0.182 & 39.6 & 0.772 & $1.22 \%$ & $23.40 \%$ \\
\hline & High & 2,784 & 62.3 & 0.046 & 0.178 & 37.6 & 0.764 & $1.20 \%$ & $21.74 \%$ \\
\hline \multirow[t]{3}{*}{ Active } & Low & 21 & 58.6 & 0.047 & 0.204 & 34.5 & 0.794 & $1.25 \%$ & $23.67 \%$ \\
\hline & Medium & 164 & 59.4 & 0.045 & 0.189 & 35.5 & 0.783 & $1.24 \%$ & $23.90 \%$ \\
\hline & High & 2,765 & 62.8 & 0.045 & 0.186 & 32.3 & 0.797 & $1.29 \%$ & $19.70 \%$ \\
\hline
\end{tabular}


A Study on the Style Investment of Equity Funds

〈표 4〉액티브펀드의 펀드규모별 스타일 측정결과(계속)

Panel B: 펀드규모별 스타일 상대순위

\begin{tabular}{|c|c|c|c|c|c|c|c|c|c|}
\hline $\begin{array}{l}\text { 스타일 } \\
\text { 유형 }\end{array}$ & $\begin{array}{c}\text { 펀드규모 } \\
\text { 그룹 }\end{array}$ & $\begin{array}{l}\text { 순자산 } \\
\text { (억원) }\end{array}$ & NPFO & HHI & ICI & SIZE & BTM & DY & MOM \\
\hline \multirow[t]{3}{*}{ Small } & Low & 33 & $47 \%$ & $21 \%$ & $61 \%$ & $16 \%$ & $46 \%$ & $45 \%$ & $82 \%$ \\
\hline & Medium & 182 & $50 \%$ & $24 \%$ & $61 \%$ & $20 \%$ & $41 \%$ & $30 \%$ & $77 \%$ \\
\hline & High & 2,118 & $65 \%$ & $8 \%$ & $51 \%$ & $7 \%$ & $54 \%$ & $52 \%$ & $78 \%$ \\
\hline \multirow[t]{3}{*}{ Value } & Low & 20 & $48 \%$ & $39 \%$ & $46 \%$ & $44 \%$ & $58 \%$ & $52 \%$ & $53 \%$ \\
\hline & Medium & 144 & $49 \%$ & $36 \%$ & $50 \%$ & $39 \%$ & $60 \%$ & $53 \%$ & $52 \%$ \\
\hline & High & 3,810 & $57 \%$ & $28 \%$ & $40 \%$ & $31 \%$ & $69 \%$ & $64 \%$ & $48 \%$ \\
\hline \multirow{3}{*}{ Growth } & Low & 29 & $53 \%$ & $35 \%$ & $56 \%$ & $41 \%$ & $50 \%$ & $33 \%$ & $60 \%$ \\
\hline & Medium & 149 & $45 \%$ & $44 \%$ & $55 \%$ & $48 \%$ & $46 \%$ & $34 \%$ & $61 \%$ \\
\hline & High & 1,079 & $53 \%$ & $41 \%$ & $55 \%$ & $46 \%$ & $43 \%$ & $34 \%$ & $58 \%$ \\
\hline \multirow[t]{3}{*}{ Dividend } & Low & 19 & $48 \%$ & $31 \%$ & $33 \%$ & $35 \%$ & $60 \%$ & $68 \%$ & $53 \%$ \\
\hline & Medium & 200 & $49 \%$ & $34 \%$ & $36 \%$ & $40 \%$ & $59 \%$ & $69 \%$ & $55 \%$ \\
\hline & High & 2,787 & $67 \%$ & $23 \%$ & $21 \%$ & $32 \%$ & $70 \%$ & $83 \%$ & $47 \%$ \\
\hline \multirow[t]{3}{*}{ SRI } & Low & 26 & $40 \%$ & $45 \%$ & $51 \%$ & $48 \%$ & $55 \%$ & $45 \%$ & $62 \%$ \\
\hline & Medium & 85 & $48 \%$ & $41 \%$ & $47 \%$ & $50 \%$ & $47 \%$ & $38 \%$ & $62 \%$ \\
\hline & High & 1,105 & $43 \%$ & $46 \%$ & $45 \%$ & $51 \%$ & $45 \%$ & $41 \%$ & $58 \%$ \\
\hline \multirow[t]{3}{*}{ Theme } & Low & 26 & $29 \%$ & $55 \%$ & $70 \%$ & $34 \%$ & $39 \%$ & $35 \%$ & $54 \%$ \\
\hline & Medium & 277 & $27 \%$ & $62 \%$ & $70 \%$ & $44 \%$ & $40 \%$ & $32 \%$ & $46 \%$ \\
\hline & High & 4,193 & $23 \%$ & $73 \%$ & $78 \%$ & $43 \%$ & $30 \%$ & $34 \%$ & $41 \%$ \\
\hline \multirow[t]{3}{*}{ General } & Low & 22 & $44 \%$ & $49 \%$ & $50 \%$ & $51 \%$ & $49 \%$ & $44 \%$ & $57 \%$ \\
\hline & Medium & 167 & $46 \%$ & $46 \%$ & $47 \%$ & $51 \%$ & $45 \%$ & $43 \%$ & $58 \%$ \\
\hline & High & 2,784 & $46 \%$ & $48 \%$ & $45 \%$ & $51 \%$ & $41 \%$ & $39 \%$ & $56 \%$ \\
\hline \multirow[t]{3}{*}{ Active } & Low & 21 & $44 \%$ & $44 \%$ & $51 \%$ & $45 \%$ & $50 \%$ & $46 \%$ & $57 \%$ \\
\hline & Medium & 164 & $45 \%$ & $43 \%$ & $50 \%$ & $46 \%$ & $48 \%$ & $44 \%$ & $57 \%$ \\
\hline & High & 2,765 & $48 \%$ & $44 \%$ & $47 \%$ & $44 \%$ & $46 \%$ & $46 \%$ & $53 \%$ \\
\hline \multicolumn{10}{|c|}{ Panel C: 펀드규모별 스타일 차이에 대한 t-test 결과 } \\
\hline $\begin{array}{l}\text { 스타일 } \\
\text { 유형 }\end{array}$ & \multicolumn{2}{|c|}{$\begin{array}{c}\text { 펀드규모 } \\
\text { 그룹 }\end{array}$} & $\begin{array}{l}\Delta \mathrm{NPFO} \\
\text { (종목) }\end{array}$ & $\Delta \mathrm{HHI}$ & $\Delta \mathrm{ICI}$ & $\begin{array}{l}\triangle \mathrm{SIZE} \\
\text { (조원) }\end{array}$ & BTM & $\Delta \mathrm{DY}$ & $\Delta \mathrm{MOM}$ \\
\hline \multirow[t]{3}{*}{ Small } & \multicolumn{2}{|l|}{ High - Low } & $\begin{array}{r}27.4 \\
(18.27)\end{array}$ & $\begin{array}{r}-0.010 \\
(-14.43)\end{array}$ & $\begin{array}{r}-0.066 \\
(-10.48)\end{array}$ & $\begin{array}{r}-8.5 \\
(-10.99)\end{array}$ & $\begin{array}{l}0.058 \\
(6.50)\end{array}$ & $\begin{array}{l}0.14 \% \\
(4.90)\end{array}$ & $\begin{array}{c}-5.80 \% \\
(-3.89)\end{array}$ \\
\hline & \multirow{2}{*}{\multicolumn{2}{|c|}{ High - Medium }} & 23.2 & -0.008 & -0.032 & -7.0 & 0.067 & $0.23 \%$ & $-4.46 \%$ \\
\hline & & & (29.30) & $(-17.08)$ & $(-13.87)$ & $(-15.84)$ & $(6.11)$ & (12.94) & $(0.37)$ \\
\hline \multirow[t]{4}{*}{ Value } & \multirow{2}{*}{\multicolumn{2}{|c|}{ High - Low }} & 25.9 & -0.010 & -0.025 & -10.7 & 0.147 & $0.28 \%$ & $-5.67 \%$ \\
\hline & & & $(15.83)$ & $(-13.47)$ & $(-8.64)$ & $(-10.21)$ & $(16.82)$ & (15.08) & $(-5.32)$ \\
\hline & \multirow{2}{*}{\multicolumn{2}{|c|}{ High - Medium }} & 20.4 & -0.006 & -0.023 & -5.5 & 0.113 & $0.25 \%$ & $-4.71 \%$ \\
\hline & & & (10.61) & $(-8.59)$ & $(-14.19)$ & $(-10.50)$ & $(13.17)$ & $(20.42)$ & $(-3.68)$ \\
\hline \multirow[t]{4}{*}{ Growth } & \multirow{2}{*}{\multicolumn{2}{|c|}{ High - Low }} & -1.2 & 0.005 & -0.008 & 3.7 & -0.027 & $-0.01 \%$ & $-0.16 \%$ \\
\hline & & & $(1.24)$ & $(7.31)$ & $(-7.70)$ & (6.98) & $(-5.39)$ & $(3.54)$ & $(-0.16)$ \\
\hline & \multirow{2}{*}{\multicolumn{2}{|c|}{ High - Medium }} & 4.1 & -0.001 & -0.002 & -2.4 & -0.016 & $-0.05 \%$ & $-0.28 \%$ \\
\hline & & & $(8.79)$ & $(-3.89)$ & $(-0.50)$ & $(-2.94)$ & $(-5.18)$ & $(-1.71)$ & $(-0.23)$ \\
\hline Dividend & \multicolumn{2}{|l|}{ High - Low } & $\begin{array}{r}28.4 \\
(29.91)\end{array}$ & $\begin{array}{l}-0.005 \\
(-8.15)\end{array}$ & $\begin{array}{r}-0.024 \\
(-14.06)\end{array}$ & $\begin{array}{r}-1.1 \\
(-2.55)\end{array}$ & $\begin{array}{r}0.152 \\
(16.49)\end{array}$ & $\begin{array}{r}0.28 \% \\
(10.36)\end{array}$ & $\begin{array}{l}-4.64 \% \\
(-2.64)\end{array}$ \\
\hline
\end{tabular}


한국증권학회지 제 50 권 2호 (2021)

〈표 4〉액티브펀드의 펀드규모별 스타일 측정결과(계속)

\begin{tabular}{|c|c|c|c|c|c|c|c|c|}
\hline $\begin{array}{l}\text { 스타일 } \\
\text { 유형 }\end{array}$ & $\begin{array}{c}\text { 펀드규모 } \\
\text { 그룹 }\end{array}$ & $\begin{array}{c}\triangle \mathrm{NPFO} \\
\text { (종목) }\end{array}$ & $\Delta \mathrm{HHI}$ & $\Delta \mathrm{ICI}$ & $\begin{array}{l}\triangle \mathrm{SIZE} \\
\text { (조원) }\end{array}$ & $\triangle \mathrm{BTM}$ & $\Delta \mathrm{DY}$ & $\Delta \mathrm{MOM}$ \\
\hline & High - Medium & 26.7 & -0.005 & -0.019 & $\begin{array}{l}-1.5 \\
\end{array}$ & 0.151 & 0. & J \\
\hline & & $(43.89)$ & $(-17.19)$ & $(-25.71)$ & $(-10.65)$ & $(22.63)$ & & $(-5.41)$ \\
\hline \multirow[t]{4}{*}{ SRI } & High - Low & -4.1 & 0.005 & -0.001 & 1.6 & -0.059 & $\%$ & $-2.76 \%$ \\
\hline & & $(4.91)$ & $(0.18)$ & $(-4.52)$ & $(0.66)$ & $(-9.05)$ & $(-2.93)$ & $(-3.47)$ \\
\hline & High - Medium & -8.9 & 0.008 & 0.002 & 4.3 & -0.032 & $0.05 \%$ & $-5.24 \%$ \\
\hline & & $(-3.10)$ & (3.66) & $(-1.98)$ & (2.13) & $(-3.72)$ & $(2.48)$ & $(-4.15)$ \\
\hline \multirow[t]{4}{*}{ Theme } & High - Low & -13.3 & 0.013 & -0.037 & 7.9 & -0.065 & $-0.01 \%$ & $-7.86 \%$ \\
\hline & & $(-11.71)$ & & $(-3.13)$ & $(8.60)$ & $(-8.32)$ & & \\
\hline & High - Medium & -8.3 & 0.006 & -0.006 & -1.5 & -0.048 & $0.01 \%$ & $-4.10 \%$ \\
\hline & & $(-6.66)$ & (1.12) & (1.39) & $(-1.90)$ & $(-10.40)$ & $(-3.42)$ & $(-2.00)$ \\
\hline \multirow[t]{4}{*}{ General } & High - Low & 0.6 & -0.005 & -0.014 & -0.5 & -0.026 & $-0.04 \%$ & $-1.40 \%$ \\
\hline & & $(-1.06)$ & $(-7.15)$ & $(-16.38)$ & $(2.81)$ & $(-15.82)$ & $(-10.89)$ & $(-2.46)$ \\
\hline & High - Medium & 0.6 & -0.001 & -0.004 & -2.1 & -0.008 & $-0.02 \%$ & $-1.66 \%$ \\
\hline & & $(-1.01)$ & $(-3.43)$ & $(-10.11)$ & $(-1.53)$ & $(-7.73)$ & $(-14.18)$ & $(-4.36)$ \\
\hline \multirow[t]{4}{*}{ Active } & High - Low & 4.2 & -0.002 & -0.018 & -2.1 & 0.003 & $0.04 \%$ & $-3.97 \%$ \\
\hline & & (10.62) & $(-6.43)$ & $(-15.71)$ & $(-1.23)$ & $(-11.08)$ & $(1.44)$ & $(-7.89)$ \\
\hline & High - Medium & 3.4 & 0.000 & -0.003 & -3.2 & 0.014 & $0.05 \%$ & $-4.20 \%$ \\
\hline & & (6.88) & $(-3.92)$ & $(-4.87)$ & $(-7.26)$ & $(2.44)$ & $(9.88)$ & $(-9.79)$ \\
\hline
\end{tabular}

상대순위가 $50 \%$ 로 성장주 스타일 특성이 전혀 없고 혼합형(Blend) 스타일임을 알 수 있다. 펀드명칭에서 표방하는 스타일 투자전략을 구사하지 않았음을 말해주며, 투자자에 대한 신인의무를 이행하였다고 보기 어려운 대목이다. 테마형에서도 펀드규모가 클수록 종목 집중도와 산업집중도가 높아지고, 보유종목수는 줄어들고 있음을 볼 때, 규모가 큰 펀드에서 테마주의 일반적인 스타일 특성이 잘 준수됨을 말해주고 있다. Panel C는 펀드규모별 스타일 차이가 통계적으로 유의한지 알아보기 위한 t-test 결과이다. 앞서 언급한 펀드규모에 따른 스타일 차이가 High 대 Low, High 대 Medium 그룹간의 비교에서 모두 통계적으로 강한 유의성을 나타내고 있다.

\section{4 스타일 지속성 검증 결과}

<그림 1>은 펀드시장 전체를 대상으로 7가지 스타일에 대하여 2009년 1월부터 2018년 12 월까지 스타일 변화 확률을 나타내는 순위분할표(contingency table)이다. 연초의 스타일 상대순위를 10 분위로 그룹화하고 특정 분위에 속한 펀드가 연말에 어떤 그룹으로 이동하는지 확률화한 다음 10 개년을 평균한 것이다. 연초에 포트폴리오 정보가 존재하던 특정펀드가 연말에 존재하지 않는 경우에는 Dead 그룹으로 처리하였다. 따라서 연초에는 10 개 그룹 으로, 연말에는 11 개 그룹으로 구분된다. 연초의 스타일을 연말까지 유지하는 확률이 높다 (막대그래프가 특정 영역에서 높이 솟아 있을수록)면 스타일 지속성이 강한 것으로 반대 (막대그래프가 고르게 퍼져 있을수록)이면 지속성이 약한 것으로 해석한다. 
A Study on the Style Investment of Equity Funds

스타일 특성이 가장 뚜렷한 1 분위 및 10 분위 그룹을 중심으로 스타일 지속확률을 살펴

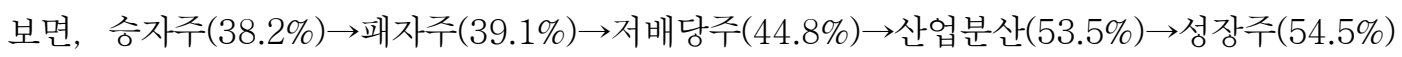
$\rightarrow$ 고배당주 $(61.3 \%) \rightarrow$ 대형주 $(61.6 \%) \rightarrow$ 종목분산 $(62.2 \%) \rightarrow$ 소형주 $(65.5 \%) \rightarrow$ 종목집중 $(65.6 \%)$ $\rightarrow$ 가치주 $(70.0 \%) \rightarrow$ 소종목 $(70.4 \%) \rightarrow$ 산업집중 $(71.1 \%) \rightarrow$ 다종목 $(73.7 \%)$ 순으로 지속성이 높았다. 승자주 및 패자주 스타일의 지속성이 가장 낮다는 점은 펀드매니저들이 모멘텀이라는 스타일 속성에 대해 일관된 전략을 구사하지 않고, 타이밍을 하고 있음을 말해주는 대목이다. 또한 가치주 스타일의 지속성에 비해 성장주 스타일 지속성이 크게 뒤쳐지고 있다. 앞서 살펴본 스타일 준수실태와 연관지어 본다면, 펀드시장에서 상품 다양성을 확보하기 위해서는 성장주 스타일 특성이 현재보다 더 보강될 필요가 있고, 성장주에 집중하여 투자하는 펀드들이 더 많이 출시될 필요가 있음을 시사하고 있다. 다종목 스타일 및 산업집중 스타일의 높은 지속성은 <표 3>, <표 4>의 결과를 감안할 때, 각각 코스피200ETF형 및 코스피200인덱스형, 테마형 및 기타지수ETF형의 영향이라고 판단된다.

\section{〈그림 1〉스타일 지속성}

연초에 존재하는 펀드들의 포트폴리오 내역을 이용하여 스타일을 계산하고, 스타일 값에 따라 스타일 상대순위 10 분위 그룹으로 구분한 후에 연초에 특정그룹에 속한 펀드가 1 년이 경과한 연말시점에 어떤 그룹으로 이동하는지를 추적하여, 가능성을 조건부 확률(conditional probability)로 계산하였다. 해당펀드가 연말에 존재하지 않는 경우 Dead 그룹으로 구분하였다. 표본기간은 2009년 1 월부터 2018년 12월까지이다. 가로축은 현재 시점을, 세로축은 1년 경과 시점을, 높이축은 전이확률을 나타 낸다. NPFO는 포트폴리오 내에 포함된 보통주 보유종목 개수이다. SCI는 각 보유종목이 차지하는 비중을 제곱하여 합산한 값이다. ICI는 포트폴리오 내에서 10 가지(IT, 경기소비재, 금융, 산업재, 소재, 에너지, 유틸리티, 의료, 통신서비스, 필수소비재) 산업이 차지하는 비중을 제곱하여 합산한 값이다. Size는 보유종목의 시가총액을 각 종목이 포트폴리오 내에서 차지하는 비중으로 가중하여 평균한 값이다. BTM은 보유종목의 장부가-시장가 비율을 각 종목이 포트폴리오 내에서 차지하는 비중으로 가중하여 평균한 값이다. $\mathrm{MOM}$ 은 보유종목의 과거 12 개월 수익률을 직전 1 개월을 제외하고 측정한 후 각 종목이 포트폴리오 내에서 차지하는 비중으로 가중하여 평균한 값이다.

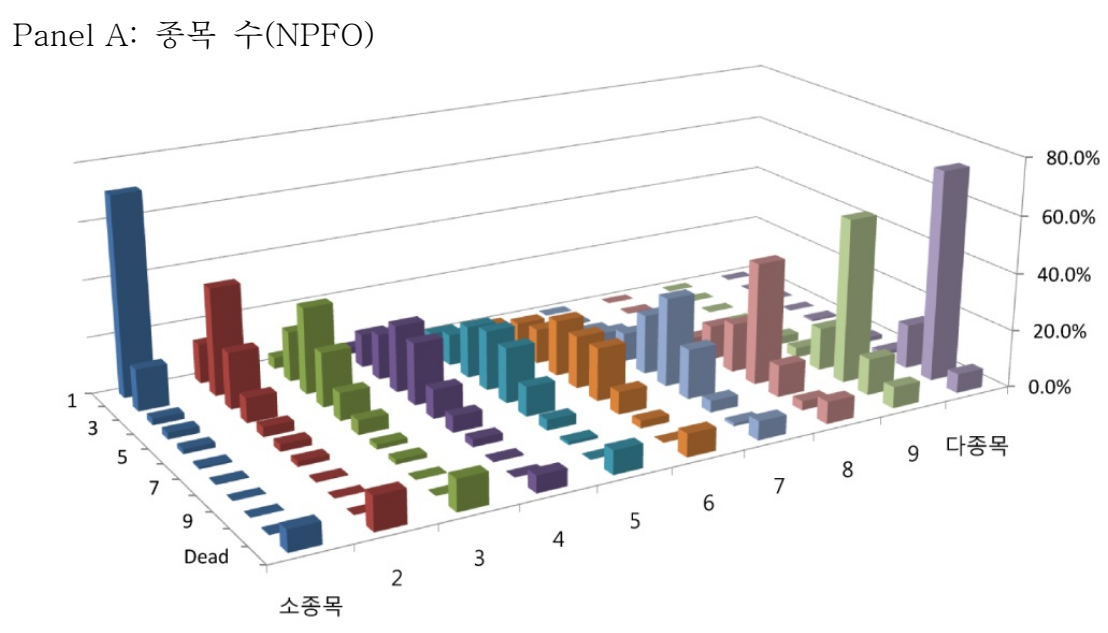


한국증권학회지 제 50 권 2호 (2021)

〈그림 1〉스타일 지속성(계속)

Panel B: 종목집중도(SCI)

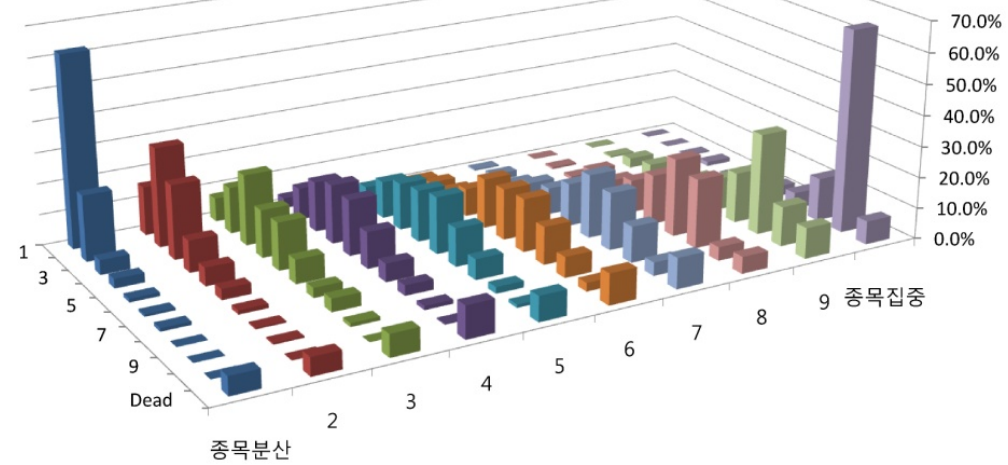

Panel C: 산업집중도(ICI)

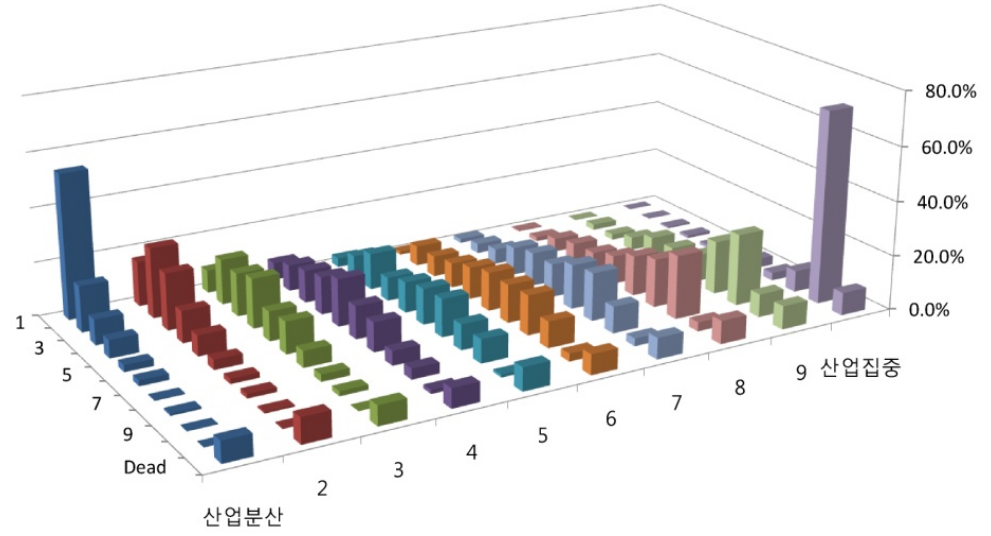

Panel D: 시가총액(Size)

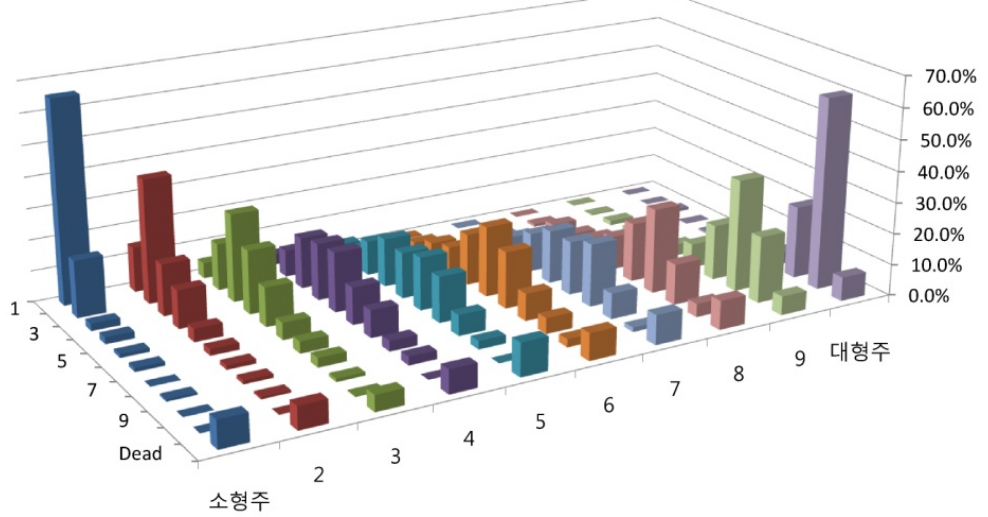


A Study on the Style Investment of Equity Funds

〈그림 1〉 스타일 지속성(계속)

Panel E: 장부가-시장가 비율(BTM)

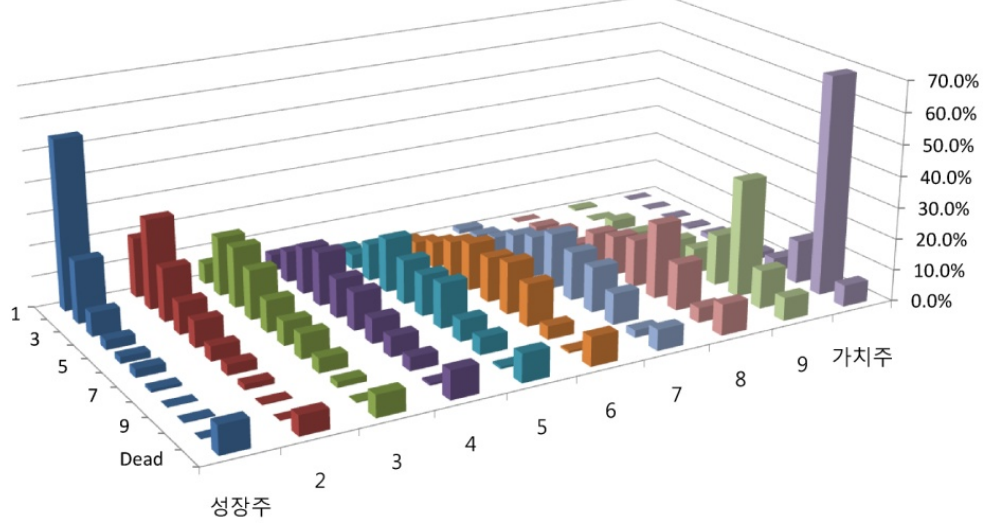

Panel F: 배당수익률(DY)

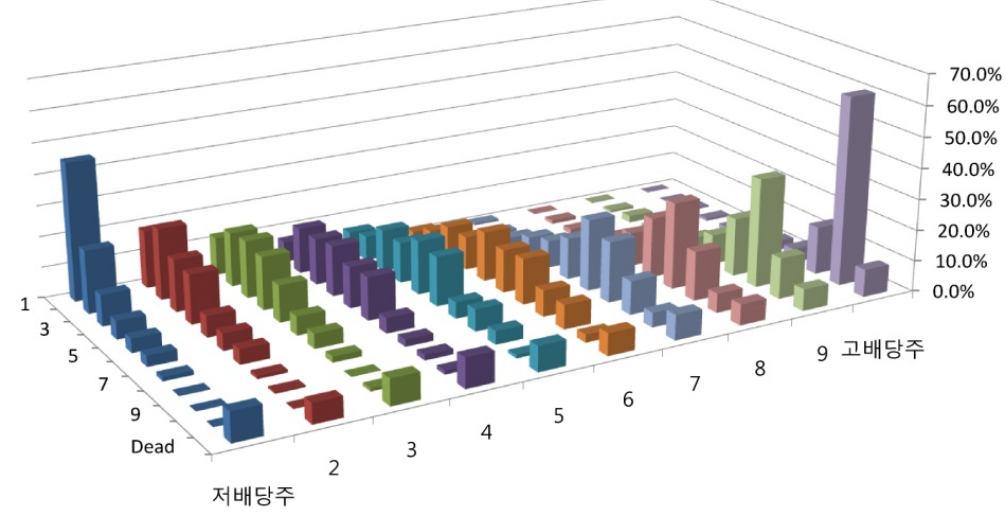

Panel G: 모멘텀(MOM)

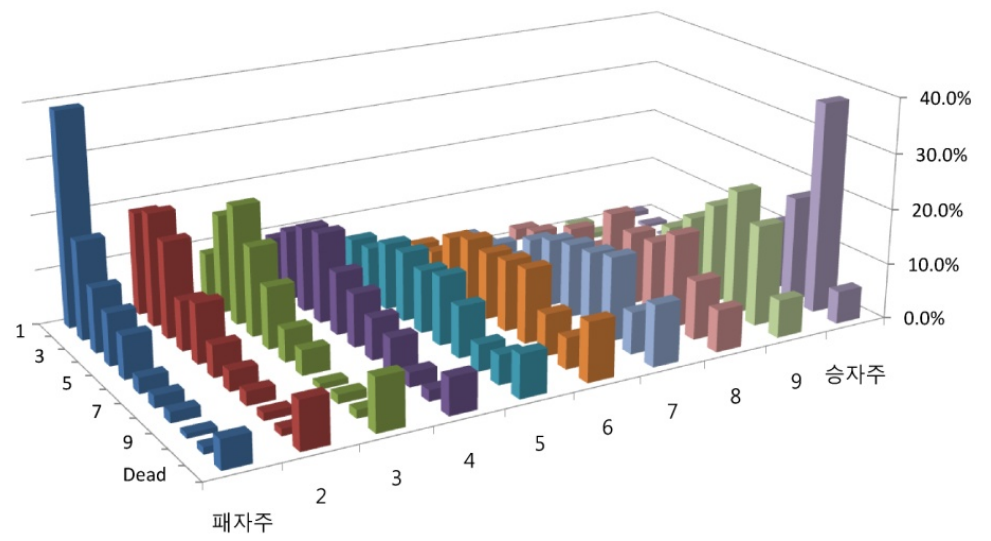




\section{5 스타일 타이밍 능력 검증 결과}

<표 5>는 월별로 측정된 4 요인 수익률에 대하여 시계열 평균과 표준편차, $t$ 통계량, 상관 계수를 계산하였다. 2009년 1월부터 2018년 12월까지 시장위험 프리미엄은 0.54\%, 소형주 프리미엄은 $0.37 \%$, 가치주 프리미엄은 $0.90 \%$, 승자주 프리미엄은 $1.01 \%$ 이다. 년간 수익률로 환산해보면 각각 $6.5 \%, 4.5 \%, 10.8 \%, 12.1 \%$ 에 해당한다. 표본기간 동안 어떤 펀드가 현금 보유를 줄이고, 소형주, 가치주, 승자주 편입비율을 높였다면 좋은 성과를 달성할 수 있었음을 의미한다. 단, 통계적 유의성은 RMRF, $\mathrm{SMB}$ 에서는 나타나지 않고 있다. 4 요인간 상관계수는 $-0.18 \sim+0.20$ 수준이다.

〈표 5〉4요인에 대한 요약통계량

월별 수익률의 시계열 평균, 표준편차, $\mathrm{t}$ 통계량, 상관계수를 나타낸다. 표본기간은 2009년 1월부터 2018년 12 월까지이다. $\mathrm{RF}$ 는 국고채 3 개월물의 수익률을 월수익률로 환산한 값이다. RM은 우리나라의 유가 증권시장 및 코스닥시장에 상장된 모든 주식을 대상으로 측정한 배당포함 시가총액가중 수익률이다. RMRF, SMB, HML, MOM은 각각 시장요인, 규모요인, 가치요인, 모멘텀요인 수익률이며 Fama and French(1993) 및 Carhart(1997)의 방법론을 우리나라 시장에 적용하여 계산하였다.

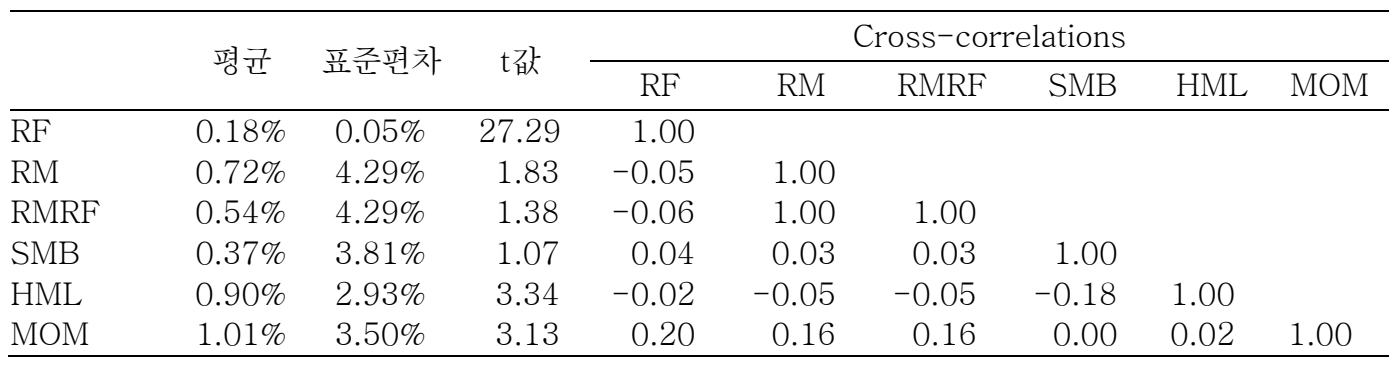

<표 6>은 스타일 타이밍 능력이 존재하는지 유형별로 검증한 결과를 제시한다. 전체 시장에서 $\mathrm{RMRF}(+)$ 요인의 회귀계수가 음수임을 볼 때, 시장요인에 타이밍 능력은 관찰 되지 않았다. 이는, 시장이 활황일 때 주식보유비중을 증가시키고 현금보유비중을 감소시키며, 시장이 불황일 때 주식보유비중을 감소시키고, 현금보유비중을 증가시키는 시장요인에 대한 타이밍이 대체로 실패하고 있음을 말해준다. $\mathrm{SMB}(+)$ 요인에 대한 회귀계수는 액티브 펀드에서 대체로 양수값을 나타내고 있지만, 통계적으로 유의하지는 않다. 소형주가 주도 하는 장세에서는 소형주 보유비중을 증가시키고, 대형주 보유비중을 감소시키며, 대형주가 주도하는 장세에서는 대형주 보유비중을 증가시키고, 소형주 보유비중을 감소시키는 규모 요인에 대한 타이밍이 대체로 어렵다는 것을 의미한다. HML(+) 요인에 대한 회귀계수는 코스피 $200 \mathrm{ETF}$ 형에서만 유의하다. 특정 패시브 펀드들이 소극적인 지수추종 전략을 근간 으로 하되, 초과수익을 일정부분 달성하기 위해 액티브 투자전략을 가미하는 인핸스드 인덱스 펀드(enhanced index fund $)^{10)}$ 로 운용된다는 점을 고려할 때, 가치주가 주도하는 장세

10) 계량적 차익거래활동, 주식대여를 통한 대차수수료 수입 창출, 포트폴리오 최적화를 통한 특정 요인 또는 섹터에 대한 편입비 조절(factor bet 또는 sector bet) 등의 전략이다. 
A Study on the Style Investment of Equity Funds

또는 성장주가 주도하는 장세에서 상황에 맞게 가치요인에 대한 노출도를 조절하는 전략에 일정부분 성과가 있었음을 의미하고 있다. 마지막으로 $\mathrm{MOM}(+)$ 요인에 대한 회귀계수는

\section{〈표 6〉스타일 타이밍 능력 검증결과}

펀드 유형별로 스타일 타이밍 능력의 존재여부를 검증한 결과이다. Active는 액티브펀드 전체를, Passive는 패시브펀드 전체를, All은 펀드 전체를 의미한다. 액티브 펀드는 펀드명칭에 특정 단어가 포함되는지 여부를 통해 스타일 유형을 분류하였고, 2개 이상의 유형(예를 들면 배당, 성장이라는 단어를 동시에 포함하는 경우)에 중복하여 분류되는 경우가 발생하였다. 패시브 펀드는 제로인의 분류기준을 토대로 하여 ETF여부에 따라 분류하였고 중복하여 분류되지 않았다. 세부적인 분류기준은 본문 및 <표 1>에 설명되어 있다. 표본기간은 2009년 1월부터 2018년 12월까지이다. RF는 국고채 3 개월물의 수익률을 월수익률로 환산한 값이다. RM은 우리나라의 유가증권시장 및 코스닥시장에 상장된 모든 주식을 대상으로 측정한 배당포함 시가총액가중 수익율이다. RMRF, SMB, HML, MOM은 각각 시장요인, 규모요인, 가치요인, 모멘텀요인 수익률이며 Fama and French(1993) 및 Carhart(1997)의 방법론을 우리나라 시장에 적용하여 계산하였다. $\mathrm{RMRF}(+), \mathrm{SMB}(+), \operatorname{HML}(+), \mathrm{MOM}(+)$ 은 각각 시장요인, 규모요인, 가치요인, 모멤텀요인의 수익률이 양수일 경우에는 요인수익률을 값을 할당하고, 다른 경우에는 0 을 할당한 타이밍 요인을 의미한다. $t$ 통계량은 괄호안에 표시하였다.

\begin{tabular}{|c|c|c|c|c|c|c|c|c|c|c|}
\hline & Alpha & RMRF & SMB & HML & MOM & $\begin{array}{c}\text { RMRF } \\
(+)\end{array}$ & $\begin{array}{c}\text { SMB } \\
(+)\end{array}$ & $\begin{array}{l}\text { HML } \\
(+)\end{array}$ & $\begin{array}{c}\mathrm{MOM} \\
(+)\end{array}$ & $\begin{array}{c}\text { Adjusted } \\
\mathrm{R}^{2} \\
\end{array}$ \\
\hline \multirow[t]{2}{*}{$\overline{\text { Small }}$} & $-0.35 \%$ & 0.860 & 0.192 & 0.203 & 0.183 & 0.002 & 0.181 & -0.354 & 0.217 & 0.866 \\
\hline & $(-0.83)$ & (12.35) & (1.87) & (1.31) & (1.80) & (0.02) & (1.14) & $(-1.63)$ & (1.48) & \\
\hline \multirow[t]{2}{*}{ Big } & $-0.35 \%$ & 1.009 & -0.087 & -0.190 & -0.066 & -0.162 & -0.114 & 0.288 & 0.162 & 0.864 \\
\hline & $(-0.88)$ & (15.33) & $(-0.90)$ & $(-1.30)$ & $(-0.68)$ & $(-1.57)$ & $(-0.76)$ & (1.41) & (1.17) & \\
\hline \multirow[t]{2}{*}{ Value } & $-0.29 \%$ & 0.911 & 0.008 & 0.109 & 0.001 & -0.035 & 0.076 & -0.103 & 0.148 & 0.973 \\
\hline & $(-1.79)$ & (33.74) & $(0.19)$ & (1.82) & $(0.02)$ & $(-0.83)$ & (1.24) & $(-1.23)$ & $(2.61)$ & \\
\hline \multirow[t]{2}{*}{ Growth } & $-0.22 \%$ & 0.952 & -0.045 & 0.030 & 0.061 & -0.029 & 0.119 & -0.107 & 0.072 & 0.966 \\
\hline & $(-1.15)$ & (29.55) & $(-0.95)$ & $(0.42)$ & (1.29) & $(-0.57)$ & (1.62) & $(-1.06)$ & (1.06) & \\
\hline \multirow[t]{2}{*}{ Dividend } & $-0.22 \%$ & 0.891 & -0.027 & 0.102 & -0.010 & -0.056 & 0.069 & -0.094 & 0.138 & 0.970 \\
\hline & $(-1.34)$ & $(32.24)$ & $(-0.66)$ & (1.66) & $(-0.24)$ & $(-1.28)$ & (1.09) & $(-1.09)$ & (2.37) & \\
\hline \multirow[t]{2}{*}{ SRI } & -0 . & 0.937 & -0.051 & 0.039 & 0.002 & 0.021 & 0.070 & -0.074 & 0.146 & 0.968 \\
\hline & 0) & (29.94) & $(-1.11)$ & $(0.55)$ & (0.05) & (0.42) & (0.98) & $(-0.76)$ & $(2.22)$ & \\
\hline \multirow[t]{2}{*}{ Theme } & $-0.50 \%$ & 0.941 & -0.002 & -0.087 & -0.120 & -0.001 & 0.026 & 0.061 & 0.240 & 0.952 \\
\hline & & (24.63) & $(-0.04)$ & $(-1.02)$ & $(-2.14)$ & $(-0.01)$ & (0.30) & (0.51) & (2.99) & \\
\hline \multirow[t]{2}{*}{ General } & $-0.34 \%$ & 0.936 & -0.080 & -0.003 & 0.010 & -0.037 & 0.089 & -0.043 & 0.114 & 0.975 \\
\hline & $(-2$ & $(35.20)$ & $(-2.05)$ & $(-0.04)$ & $(0.25)$ & $(-0.88)$ & (1.47) & $(-0.52)$ & (2.04) & \\
\hline \multirow[t]{2}{*}{ Active } & $-0.31 \%$ & 0.932 & -0.044 & 0.028 & 0.009 & -0.038 & 0.084 & -0.071 & 0.129 & 0.976 \\
\hline & $(-1.96)$ & $(36.01)$ & $(-1.15)$ & $(0.48)$ & $(0.24)$ & $(-0.93)$ & (1.42) & $(-0.88)$ & $(2.38)$ & \\
\hline \multirow[t]{2}{*}{$\overline{\mathrm{K} 200 \mathrm{ETF}}$} & $-0.12 \%$ & 1.017 & -0.180 & -0.161 & -0.090 & -0.004 & -0.011 & 0.203 & 0.047 & 0.971 \\
\hline & $(-0.63)$ & $(32.57)$ & $(-3.86)$ & $(-2.29)$ & $(-1.94)$ & $(-0.08)$ & $(-0.15)$ & (2.06) & $(0.71)$ & \\
\hline \multirow[t]{2}{*}{ Other ETF } & $-0.13 \%$ & 1.004 & 0.043 & 0.138 & -0.049 & 0.011 & -0.040 & -0.113 & -0.001 & 0.974 \\
\hline & $(-0.72)$ & $(24.21)$ & (1.00) & (2.09) & $(-1.13)$ & $(0.16)$ & $(-0.59)$ & $(-1.23)$ & $(-0.02)$ & \\
\hline \multirow[t]{2}{*}{ K200 Index } & $-0.18 \%$ & 1.033 & -0.162 & -0.140 & -0.100 & 0.007 & -0.037 & 0.182 & 0.065 & 0.973 \\
\hline & $(-0.97)$ & (32.95) & $(-3.65)$ & $(-2.08)$ & $(-2.28)$ & $(0.14)$ & $(-0.54)$ & (1.94) & (1.02) & \\
\hline \multirow[t]{2}{*}{ Other Index } & $0.09 \%$ & 1.082 & -0.049 & 0.109 & -0.108 & -0.080 & -0.055 & -0.102 & 0.040 & 0.986 \\
\hline & & $(24.60)$ & $(-1.60)$ & (2.36) & $(-3.55)$ & $(-1.16)$ & $(-1.16)$ & $(-1.58)$ & $(0.92)$ & \\
\hline \multirow[t]{2}{*}{ Passive } & $-0.01 \%$ & 1.039 & -0.073 & 0.012 & -0.070 & -0.018 & -0.048 & 0.008 & 0.017 & 0.990 \\
\hline & $(-0.12)$ & $(40.90)$ & $(-2.78)$ & $(0.31)$ & $(-2.70)$ & $(-0.44)$ & $(-1.18)$ & $(0.14)$ & $(0.47)$ & \\
\hline \multirow[t]{2}{*}{$\overline{A l l}$} & $-0.23 \%$ & 0.952 & -0.052 & 0.027 & -0.016 & -0.026 & 0.050 & -0.054 & 0.104 & 0.986 \\
\hline & & $(47.90)$ & $(-1.77)$ & $(0.61)$ & $(-0.56)$ & $(-0.82)$ & (1.09) & $(-0.87)$ & $(2.50)$ & \\
\hline
\end{tabular}


한국증권학회지 제 50 권 2호 (2021)

전체시장 및 액티브 펀드 유형에서 유의하게 관찰되고 있으며, 액티브 유형 중에서는 5 개 (가치형, 배당형, 사회적책임투자형, 테마형, 일반주식형)의 하위 유형에서 유의하다. 펀드 매니저들이 모멘텀(추세추종) 전략 또는 역모멘텀(추세역추종) 전략을 구사함에 있어 시장 상황에 따라 모멘텀 요인에 대한 노출도를 조절하는 타이밍 전략이 유효했음을 의미한다.

\section{6 펀드 스타일 실제유형 대 가상유형 비교 결과}

<표 7>은 다양한 측면에서 스타일 실제유형과 가상유형을 비교하기 위하여 유형간 상관관계, 펀드투자자가 지불하는 비용, 스타일요인에 대한 노출도 및 초과성과 창출능력, 유형별 성과를 분석한 결과이다. 이번 절에서는 각 유형을 빈번하게 언급하면서 비교하므로 혼돈을 피하기 위해서 유형 명칭을 영문으로 사용하면서 설명하기로 한다.

\subsection{1 펀드 스타일 유형간 상관계수}

Panel A와 Panel B는 동일한 스타일 유형에 속하는 펀드들의 수익률을 매월 동일가중 횡단면 평균한 후 연결하여 스타일 유형 수익률 시계열을 구한 후 스타일 유형 간의 상관 계수를 계산하여 행렬로 표시하였다. 분산투자효과를 극대화하려는 투자자라면 이와 같은 유형간 상관계수를 유용하게 활용할 수 있을 것이다.

실제유형에서 서로 반대되는 스타일을 표방하는 Value 및 Growth 유형 간의 상관계수는 0.989로 펀드명칭에서 표방하는 바와는 다르게 두 유형이 스타일 차별성이 낮음을 말해 준다. 흥미롭게도 Value 및 Growth와 대응되는 가상유형의 BTM Top 및 BTM Bottom 유형 간의 상관계수는 0.876 으로 실제유형 펀드들이 스타일을 준수하였더라면 상관계수가 상당히 감소할 수 있음을 말해주고 있다.

실제유형의 액티브 펀드 중에서 높은 시장 점유율을 보였던 Value 및 Dividend 유형 간의 상관계수가 무려 0.993 에 달할 정도로 두 유형이 서로 비슷한 스타일임을 말해준다. 두 유형과 대응되는 가상유형의 BTM Top 및 DY Top 유형의 상관계수도 0.987로 크게 다르지 않은 수치를 보여주고 있다. 실제유형의 펀드들이 해당 스타일을 준수하였더라도 분산투자효과 측면에서 두 유형의 펀드를 각각 보유함으로써 얻는 실익이 크지 않음을 말해 준다.

실제유형에서 가장 낮은 상관계수 0.743 은 K200 ETF 및 Small 유형 간에서 도출된다. 현재 시장에서 가장 인기있는 패시브 펀드 유형인 K200 ETF가 대형주 중심으로만 포트 폴리오가 구성된다는 약점이 있기 때문에 분산투자효과 측면에서 Small유형이 이러한 약점을 보완할 수 있음을 말해준다. <표 3>의 Panel A에서 살펴보았듯이 K200 ETF 유형의 보유종목 개수가 가장 많고, 시가총액이 가장 컸음을 감안할 때 K200 ETF 유형은 실제 유형에서 NPFO Top 및 Size Top과 관계가 있음을 유추할 수 있다. Small과 대응되는 가상 유형의 Size Bottom과 두 유형(NPFO Top 및 Size Top) 간의 상관계수도 또한 0.819와 0.789 로써 가상유형에서도 가장 낮은 값을 나타내고 있다. 
A Study on the Style Investment of Equity Funds

\subsection{2 펀드 스타일 유형별 보수 및 수수료}

Panel C와 Panel D는 펀드의 보수 및 수수료를 매월 말 같은 유형 내에서 횡단면 동일 가중 평균한 후에 표본기간동안 시계열 평균한 값을 보여준다. 실제유형에서 총보수가 가장 저렴한 유형은 $\mathrm{K} 200 \mathrm{ETF}$ 로써 액티브펀드 평균치 $1.50 \%$ 의 $1 / 10$ 에도 못 미치는 $0.14 \%$ 를 나타내고 있다. 이러한 저렴한 비용으로 인해 <표 2>의 Panel D에서 살펴보았듯이 K200 $\mathrm{ETF}$ 유형이 펀드시장을 빠르게 장악해 나갈 수 있었음을 짐작케 하는 대목이다. 액티브 펀드로 구분되는 8 개 유형의 총보수는 $1.42 \sim 1.62 \%$ 정도로 유형 간에는 총보수의 차이가 크지 않은 것으로 보인다. 펀드환매를 억제하고 장기투자를 유도하고자 부과하는 일회성 비용인 수수료가 가장 높은 유형은 Small 로써 $0.36 \%$ 를 나타낸다. 중소형주에 투자하는 펀드일수록 주식매매시 유동성충격에 취약(Chen et al., 2004; Pollet and Wilson, 2008; Chan et al., 2009)함을 감안할 때 해당유형의 펀드들이 잦은 매매로 인한 유동성충격비용을 감소시키고자 수수료를 높게 부과하는 것으로 판단된다. 가상유형에서 주목할 만한 점은 $\mathrm{MOM}$ Top 유형의 총보수가 가장 높게 나타난다는 것이다. 높은 보수를 부과하였던 액티브 펀드들이 모멘텀 전략을 활발하게 구사하며 보수가 저렴한 패시브 펀드들은 상대적으로 모멘텀 스타일 성향이 약함을 말해주고 있다.

\subsection{3 펀드 스타일 유형별 4요인모형 분석결과}

Panel E와 Panel F는 Panel E와 Panel F는 펀드 유형별로 4요인 모형을 분석하여 요인 계수(factor loadings) 및 순수익률 기준 초과성과(net alpha)를 추정하고, 유형별 보수 및 수수료를 더하여 총수익률 기준 초과성과(gross alpha)를 추정한 결과이다.

실제유형 $\mathrm{Small}$ 은 $\mathrm{SMB}, \mathrm{MOM}$ 요인 모두에서 요인계수의 유의성이 매우 높게 관찰되고 있다. 중소형주 투자를 표방한 Small 유형 펀드들이 중소형주 스타일뿐만 아니라 모멘텀 스타일을 동시에 추구했음을 말해준다. Small과 대응되는 가상유형의 Size Bottom에서도 이러한 성향은 유지되지만 $\mathrm{MOM}$ 에 대한 요인계수가 $1 / 3$ 로 수준으로 줄어들며, 계수의 유의 성도 Small에 비해 크게 감소하였다.

Value 유형에서는 흥미롭게도 HML 요인에 대한 유의성이 가장 낮고, 오히려 SMB요인 및 MOM요인에 대한 유의성이 더 높게 나타난다. 가치주 투자를 표방한 Value 유형에서 중소형주 스타일 및 모멘텀 스타일을 동시에 추구했음을 말해준다. Value와 대응되는 가상 유형의 BTM Top 에서는 HML요인에 대한 요인계수 및 유의성의 모두 3배 정도 증가하여 가치주 투자성향이 더욱 뚜렷해졌다. 가치주 투자를 표방한 펀드들이 가치주 스타일 성향을 더욱 증가시킬 수 있음을 말해준다. 반면에 $\mathrm{SMB}$ 요인에서는 별다른 차이가 없고 $\mathrm{MOM}$ 요인에서는 유의성이 사라지고 있다.

Growth 유형에서는 흥미롭게도 HML 요인에 대한 유의성의 관찰되지 않고, MOM요인 에서만 유의성이 높다. 성장주 투자를 표방한 Growth 유형에서 실제 투자는 성장주 스타일의 주식이 아니었음을 말해준다. Growth와 대응되는 가상유형의 BTM Bottom에서는 전혀 
한국증권학회지 제 50 권 2호 (2021)

다른 결과가 나타나고 있다. HML요인에 대한 요인계수가 음수이면서 t값 또한 강한 유의 성을 나타내고 있다. 성장주 투자를 표방한 펀드들이 성장주 스타일 성향을 더욱 증가시킬 수 있음을 말해준다.

실제유형에서 Active 유형은 대체로 모멘텀 스타일 성향을 Passive 유형은 역모멘텀 스타일 성향을, 펀드시장 전체에서는 모멘텀 스타일 성향이 나타나고 있음을 알 수 있다. Net Alpha를 살펴보면 Active 및 Passive 유형은 월간 위험조정 수익률이 각각 $-15 \mathrm{bp}$, $-4 \mathrm{bp}$ 를 나타내고 있다. 년간으로 환산할 경우 액티브 펀드 투자자는 $1.8 \%$, 패시브 펀드 0.48\%씩 손해를 보고 있음을 의미한다. Net Alpha에 보수를 더해준 Gross Alpha는 0에 가까운 값임을 감안할 때 이러한 저성과의 대부분은 펀드보수에서 기인함을 알 수 있다. 한편, K200 ETF 및 K200 Index 유형은 Net Alpha, Gross Alpha가 모두 다른 유형에 비해 크게 나타나고 있다. 저비용으로 인한 이점뿐만 아니라, 초과성과 창출 측면에서도 운용 능력이 우수한 유형임을 말해준다.

\subsection{4 펀드 스타일 유형별 성과 분석결과}

Panel G는 실제 스타일 유형별 성과를 분석한 결과이다. 수익률 기준으로는 K200 ETF, Dividend, Small, K200 Index형 순으로, 위험과 수익률을 동시에 고려하는 샤프지수 기준 으로는 Dividend, K200 ETF, Value, K200 Index형 순으로 우수한 성과를 보이고 있다. 표본기간 동안 소형주 프리미엄이 존재하는 상황에서 대형주 중심으로 운용되는 $\mathrm{K} 200$ $\mathrm{ETF}, \mathrm{K} 200$ Index형 수익률이 높다는 점은 저비용 패시브 펀드의 우수성을 확인시켜 주는 결과이다. 펀드수가 지나치게 적은 $\mathrm{Big}$ 유형을 제외하면 Other ETF, SRI, Theme, Other Index형 수익률이 가장 낮게 나타나고 있다. Other ETF, Other Index형은 시장지수가 아닌 특정 산업, 테마, 그룹 등을 지수화 하고, 이러한 지수를 추종한다는 점에서 Active 유형 중 Theme형과 비슷한 성격을 나타내는 것으로 보이며, 사회적책임투자는 테마주 투자의 한 형태로 볼 수 있음을 시사한다. 샤프지수를 기준으로 하더라도 Other ETF, SRI, Theme, Other Index형이 가장 낮은 값을 보이고 있다. All, Active, Passive 그룹의 수익률을 비교하면 Passive > All > Active 순으로 나타나고 있어 Sharpe(1991), Bogle(2007), Fama and French (2009)가 주장한 균형회계(Equilibrium Accounting) ${ }^{11)}$ 에 대체로 부합하는 결과라 하겠다.

Panel H는 스타일 상대순위를 기반으로 가상 스타일 유형별 성과를 분석한 결과이다. 스타일 특성이 가장 뚜렷한 Bottom(하위 $10 \%$ ), Top(상위 10\%) 그룹을 통해 결과를 살펴 보면, 샤프지수를 기준으로 성과가 우수한 스타일 유형은 BTM Top, SCI Bottom, MOM Top, DY Top 순서이다. 성과가 저조한 스타일 유형은 MOM Bottom, BTM Bottom, $\mathrm{NPFO}$ Bottom, DY Bottom, SCI Top 순서이다. 〈표 5>에서 살펴보았듯이 표본기간 동안

11) 패시브 투자자 집합과 액티브 투자자 집합이 시장전체를 구성하는 부분집합임을 고려하였을 때, 패시브 투자자 집합과 액티브 투자자 집합이 비용공제 전에는 동일한 수익률을 달성하고, 비용 공제 후에는 패시브 투자자 집합이 더 나은 수익률을 달성한다는 내용이다. 


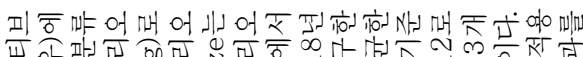

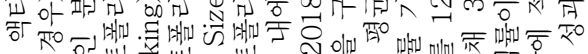

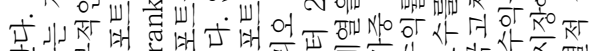

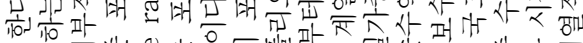

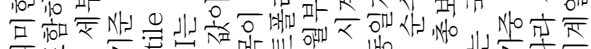

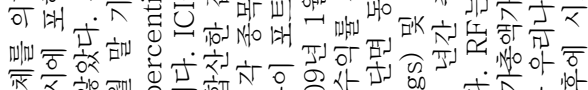

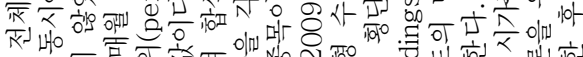

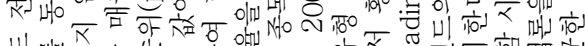
U1 面

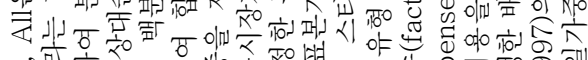

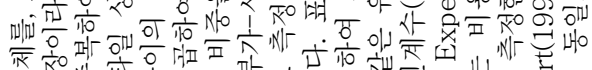

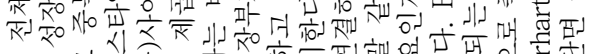

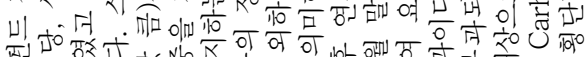

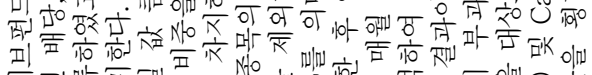

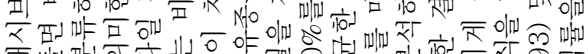

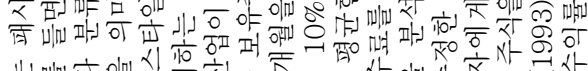
抑地

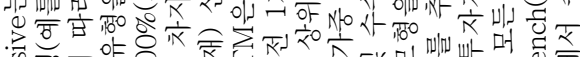
뎐. 2

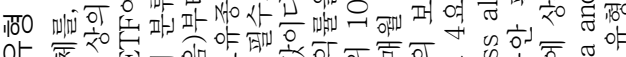

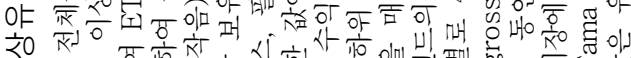

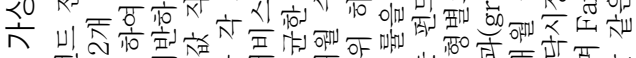

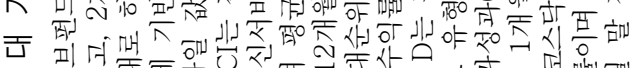

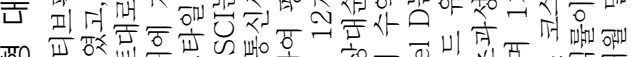

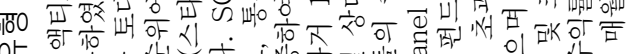

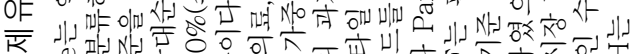
राय.

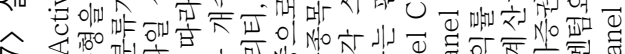

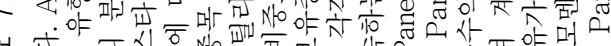
明

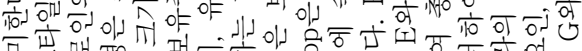

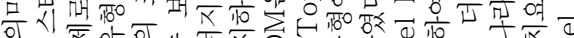

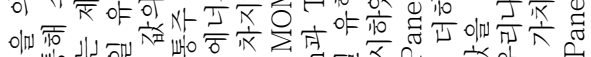

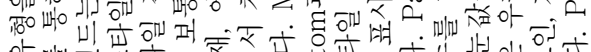

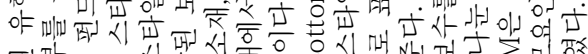

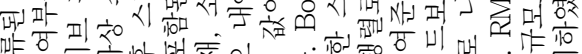

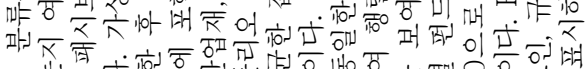

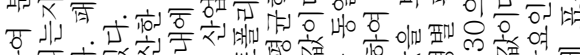

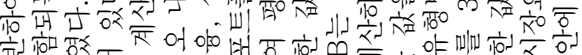

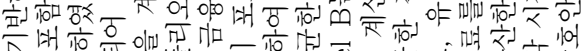

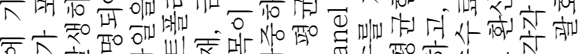

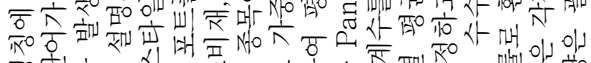

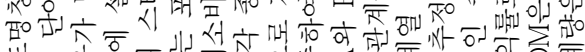

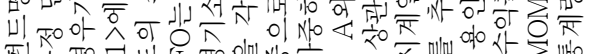

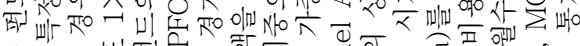
o|

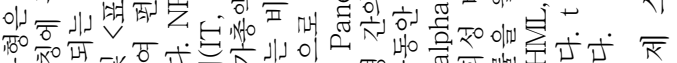

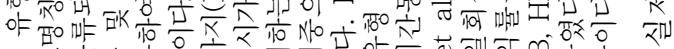

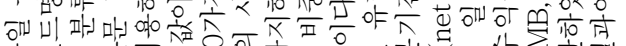

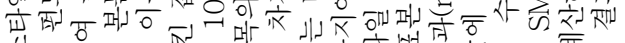

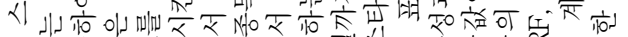

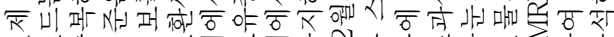

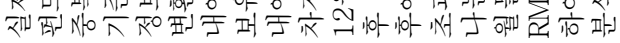

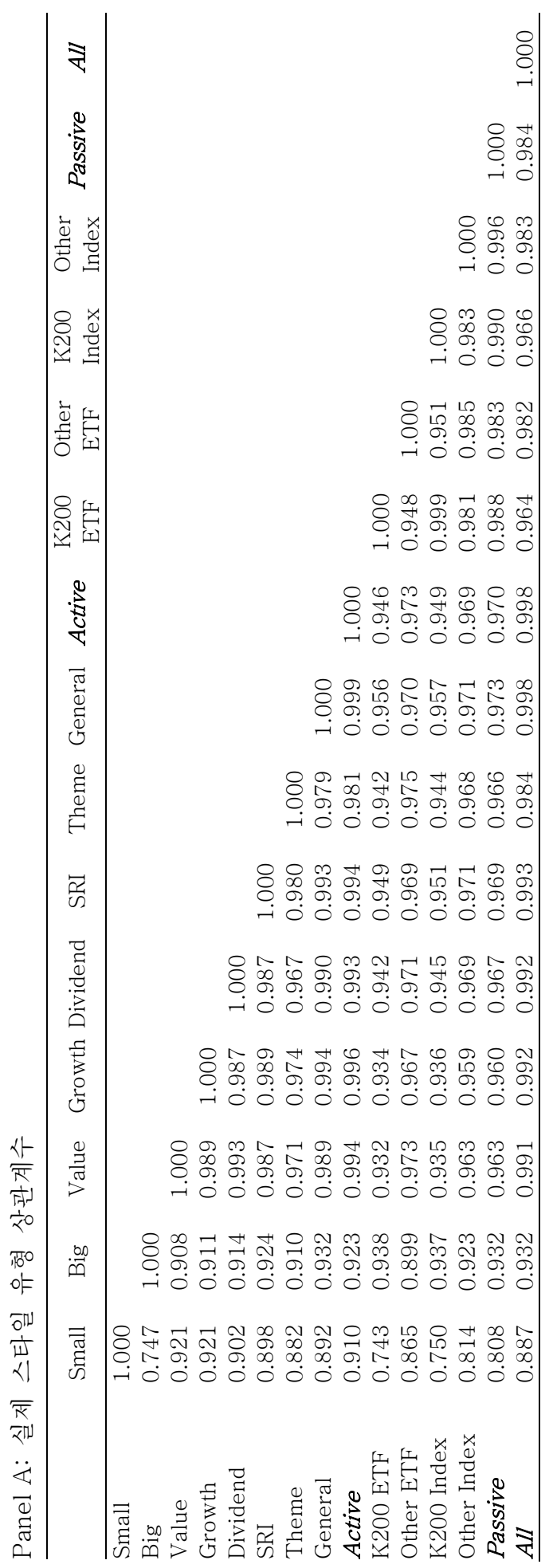



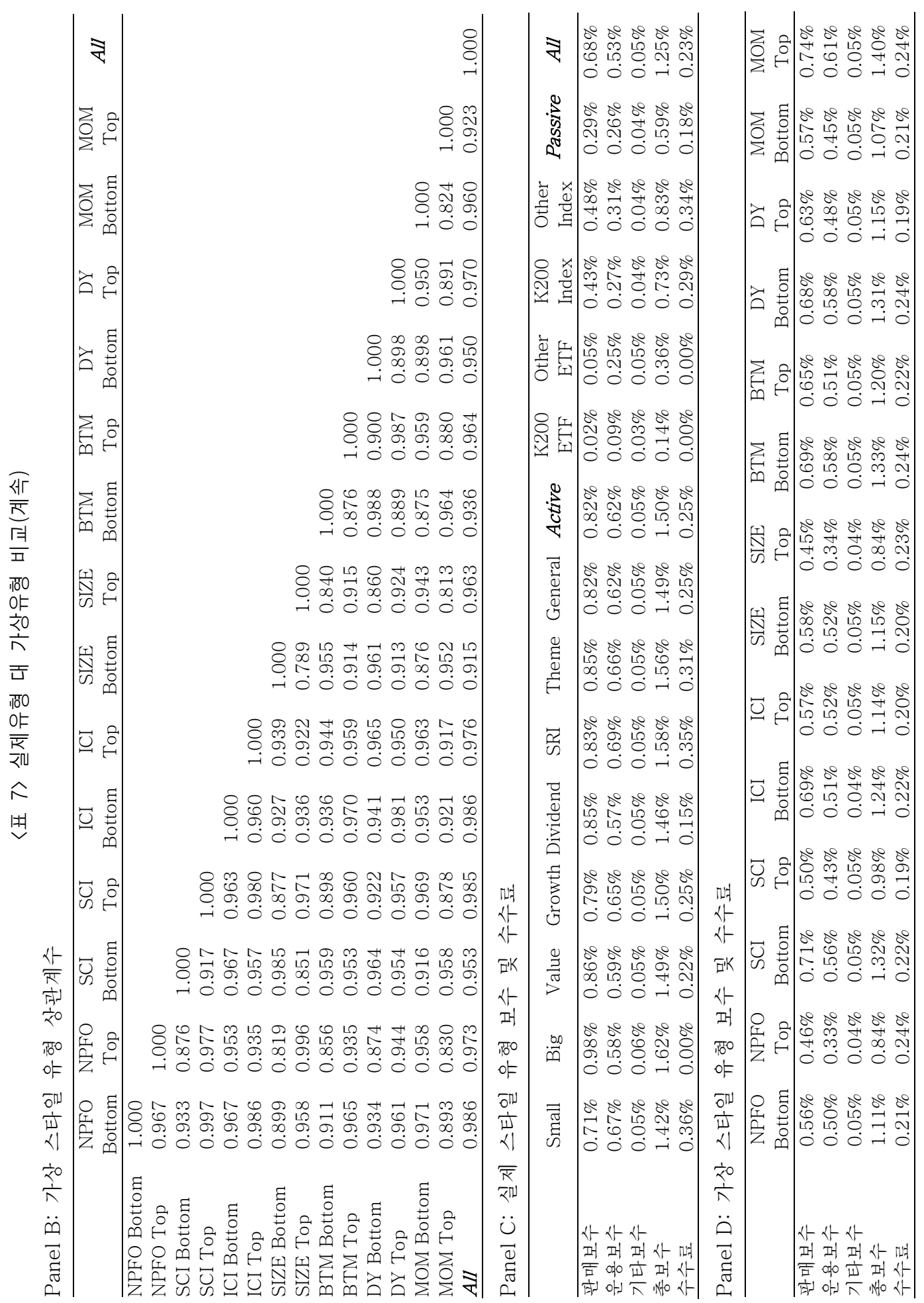


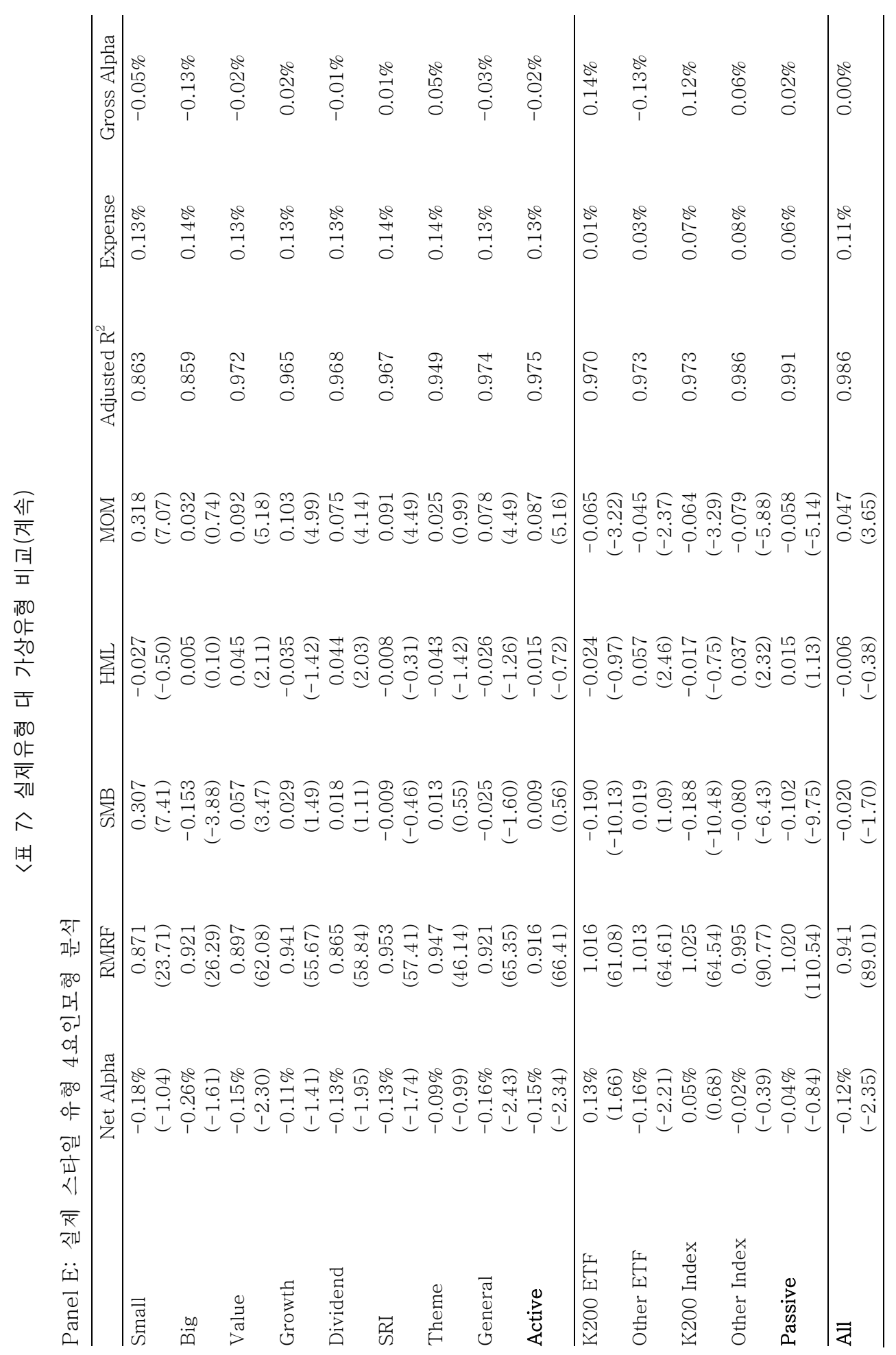


한국증권학회지 제50권 2호 (2021)

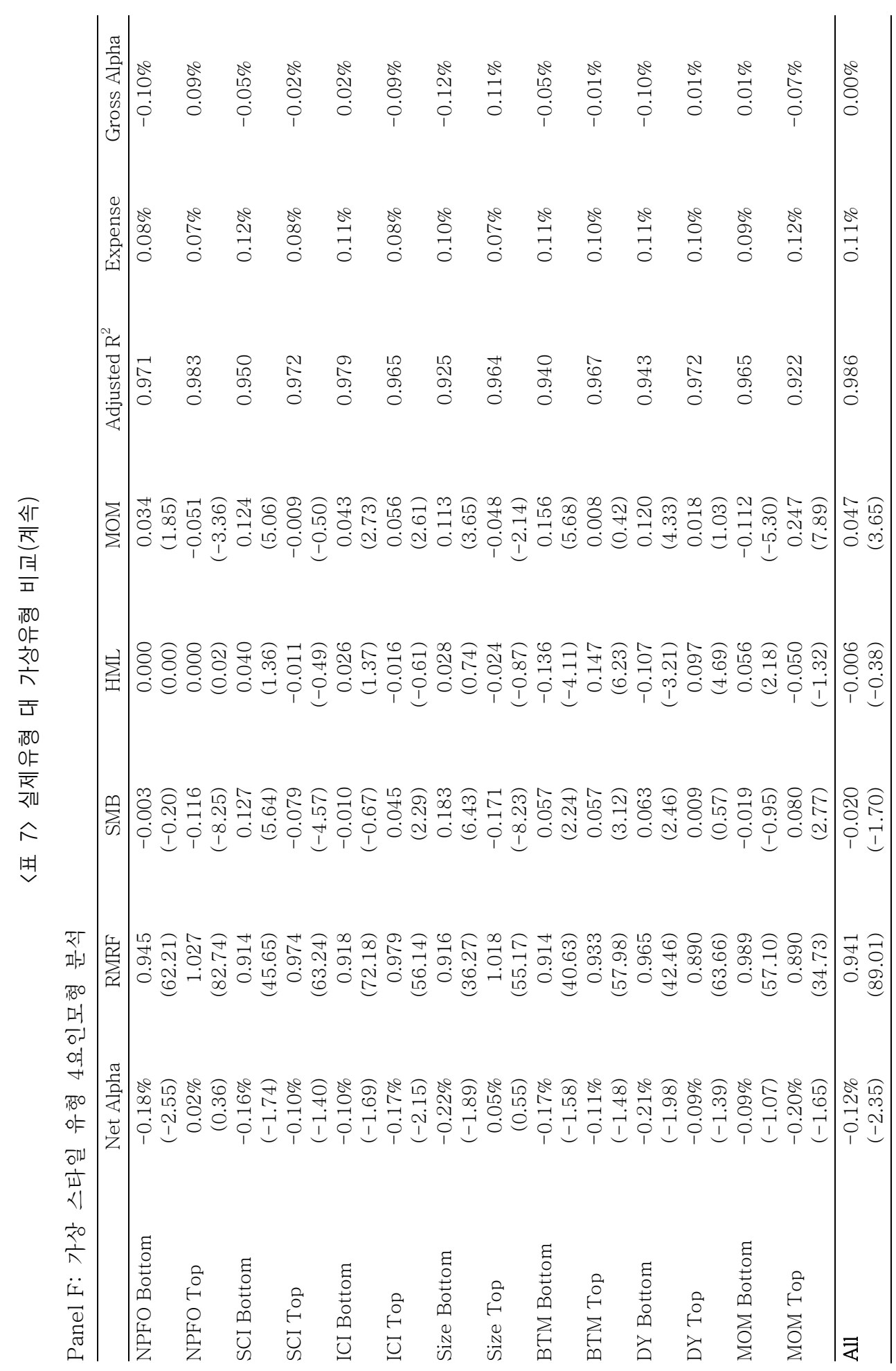




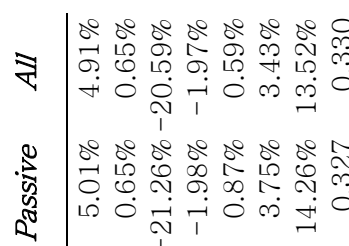

×

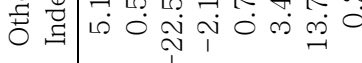

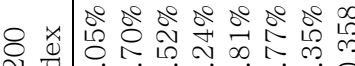

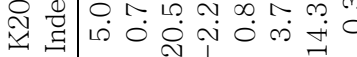

- $\quad$ ¿ீ

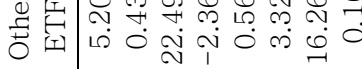

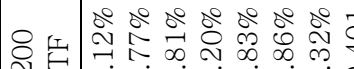

缽红

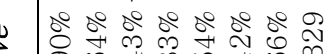

究

o do jo so do do a

T.

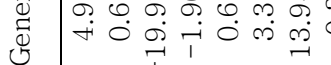

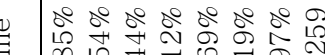

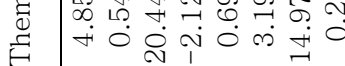

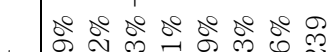

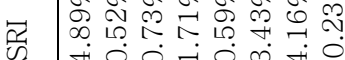

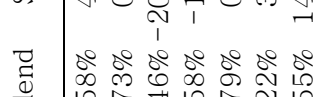

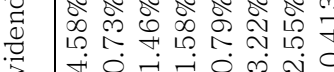

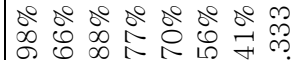

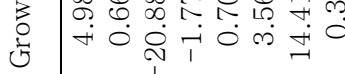

ने

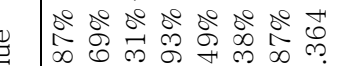

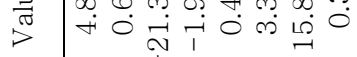

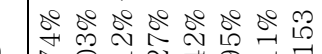

荡

人)

रूग

$\ddot{\zeta}$

Ð

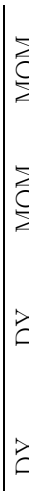

ஃீ ڤீ

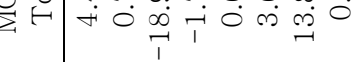

马

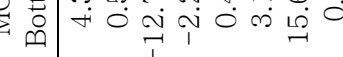

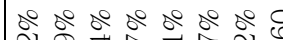

ไี คิ

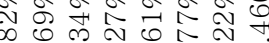

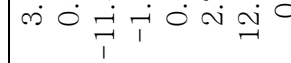

듈

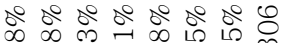

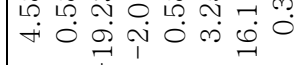

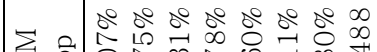

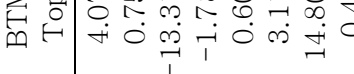

\

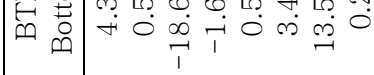

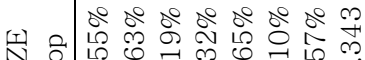

Vै

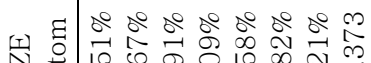

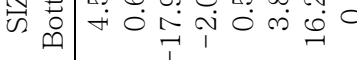

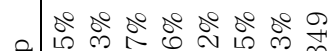

U.

घี

包

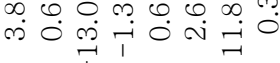

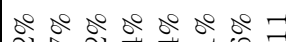

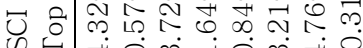

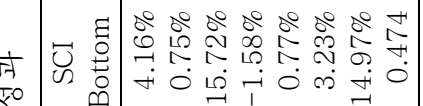

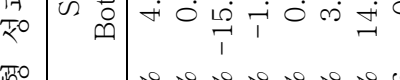

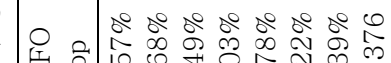

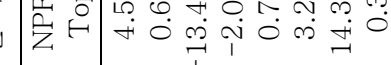

○

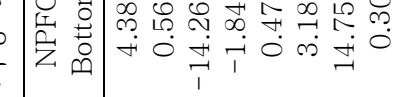

夜

菏

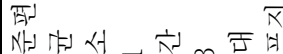

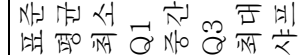


Ш

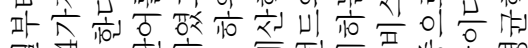

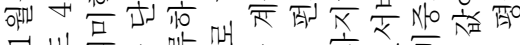

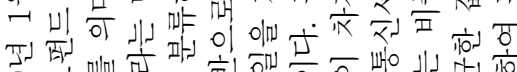

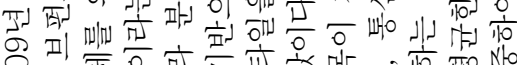

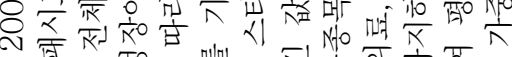
o|d - या एक

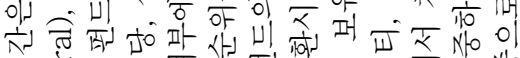

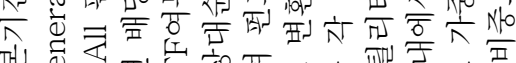

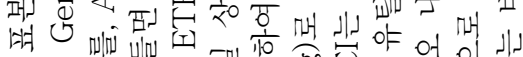

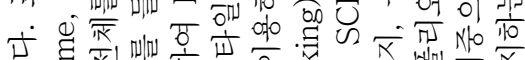
त्र 宊

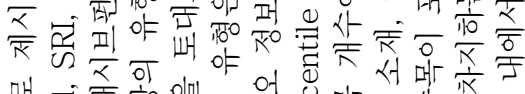

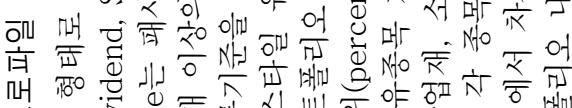

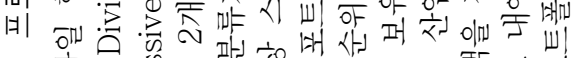
呲安

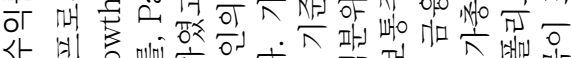
〈卜

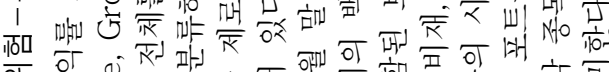

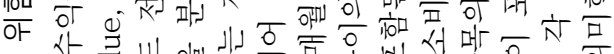
वा तु

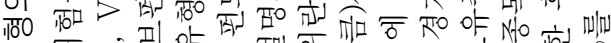

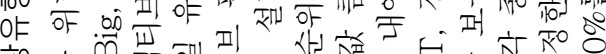

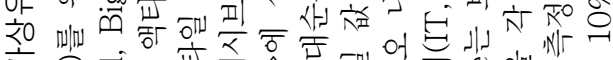

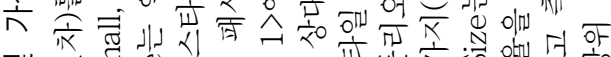

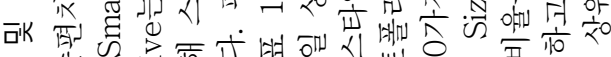
io $N$ N

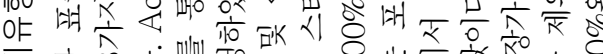

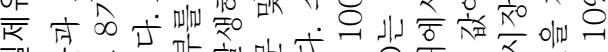

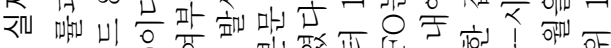

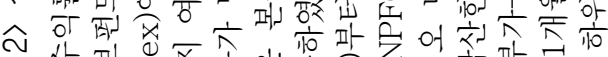

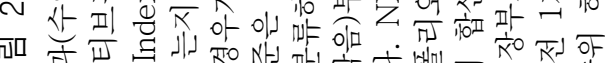

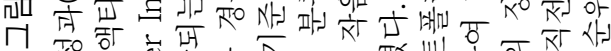
एँ

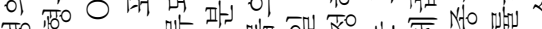
of of 空穴胙

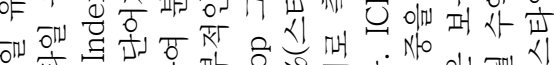

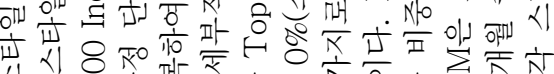

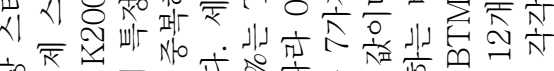

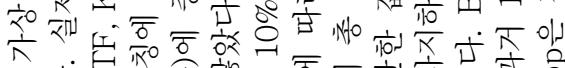
=1

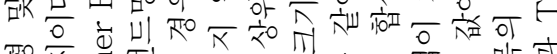

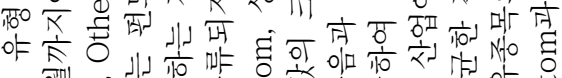

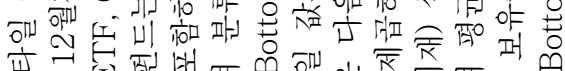

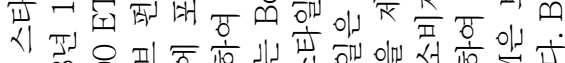

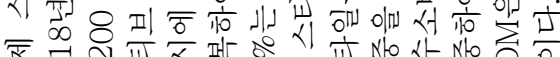

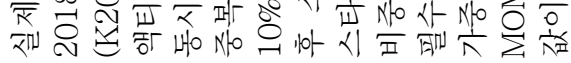

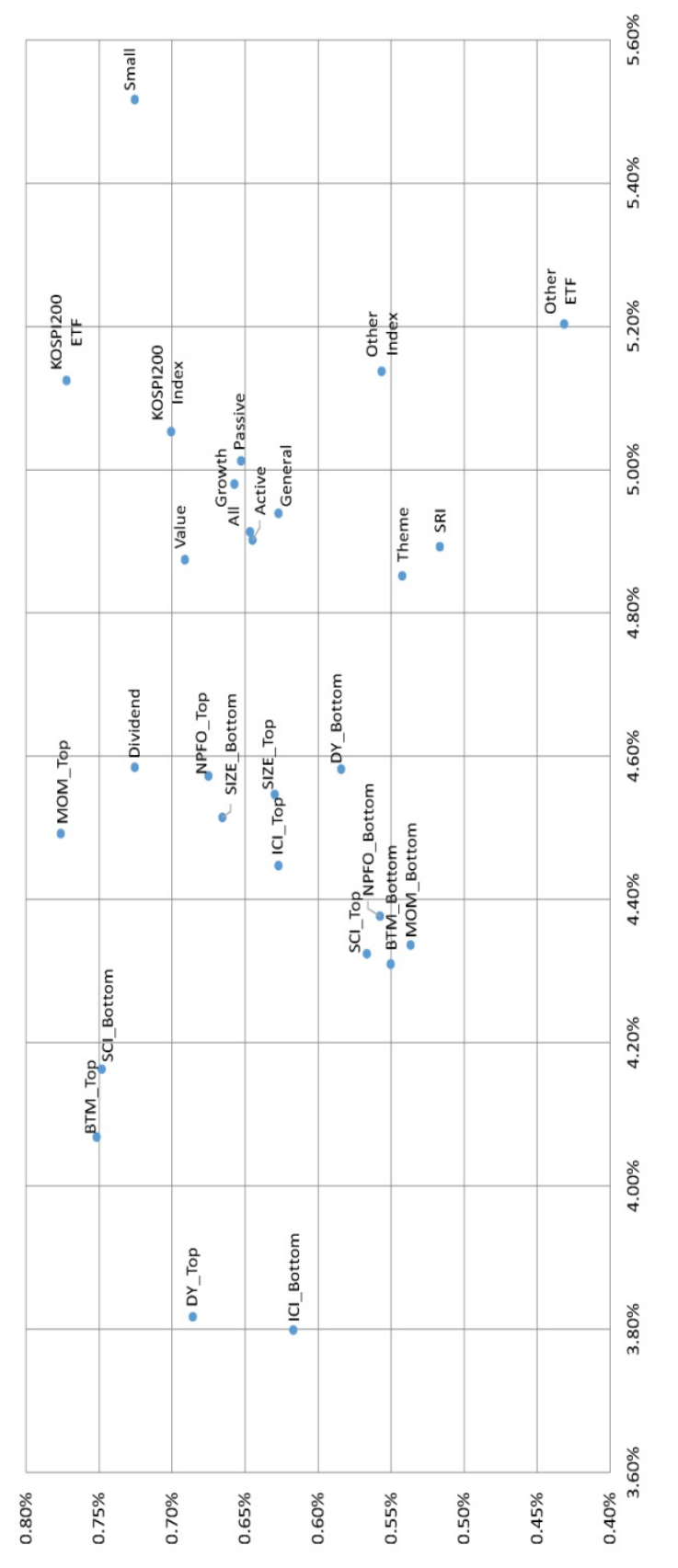




\section{A Study on the Style Investment of Equity Funds}

가치주 프리미엄과 모멘텀 프리미엄이 유의하게 존재했음을 고려하면, 일관되게 가치주 및 고배당주, 승자주 투자스타일을 유지했었다면 좋은 성과를 달성할 수 있었고 반대로 성장주, 저배당주, 패자주 투자스타일을 유지했었다면 저조한 성과를 도출하게 됨을 의미한다. 한편, 종목집중도가 가장 낮은 SCI Bottom 유형의 성과가 우수하다는 점, 보유종목수가 가장 작은 $\mathrm{NPFO} \mathrm{Bottom}$ 유형의 성과가 저조하다는 점은 분산투자의 중요성을 실증적으로 입증 해주는 결과라고 하겠다. 이상의 결과들은 그룹화 기준을 하위 $20 \%$ 및 상위 $20 \%$ 로 완화 하더라도 거의 유사하게 관찰되는데 지면관계상 구체적인 결과는 포함시키지 않았다.

<그림 2>는 실제유형과 가상유형의 성과를 모두 risk-return profile 형태로 표시하였다. 먼저 눈에 띄는 점은 가상유형에 비하여 실제유형의 위험이 전반적으로 높다는 사실이다. 펀드들이 펀드명칭에서 드러나는 특정한 스타일을 표방하면서도 일관된 스타일 속성을 지속 적으로 유지하지 않고 스타일을 타이밍 하거나, 표방하는 스타일 외의 다른 스타일 속성을 가미하고 있음을 시사한다. 몇 가지 유형들은 증대된 위험에 상응하여 수익률 역시 증대 시키고 있는데, Dividend 유형이 DY Top에 비해, Small 유형이 Size Bottom에 비해, Growth 유형이 BTM Bottom에 비해 위험과 수익률이 모두 크게 나타난다.

가상유형이 실제유형을 지배(dominate)하는 경우도 관찰되고 있다. BTM Top은 Value 유형에 비해 위험은 작고 수익률은 높아 Value형을 지배한다. 가치주 스타일을 일관되게 추구하였다면 펀드의 성과가 더욱 우수해질 수 있었는데 실제현실에서는 그렇지 못했음을 알 수 있다. 수익률뿐만 아니라 샤프지수 측면에서도 가장 성과가 저조했던 Other ETF, SRI, Theme, Other Index형은 NPFO Top, SCI Bottom, ICI Bottom에 의해 지배당하고 있다. 단순하게 분산투자(많은 보유종목수, 낮은 종목집중도, 낮은 산업집중도)를 일관되게 유지하는 투자전략만으로도 펀드시장의 여러 실제유형보다 우월한 성과를 도출한다는 사실은 분산투자의 중요성을 새삼 깨닫게 해준다.

$\mathrm{MOM}$ Top 유형은 가상유형 중 유일하게 모든 실제유형을 지배하고 있다. 표본기간동안 뚜렷한 승자주 스타일을 일관되게 유지하는 단순한 투자전략만으로도 우월한 성과를 달성할 수 있었다는 사실은 앞으로 추세추종(모멘텀) 전략을 추구하는 스타일 유형이 펀드시장에 새롭게 출현하여 투자자들에게 더 많은 선택지를 제공할 수 있음을 시사한다.

지금까지 펀드 스타일의 실제유형과 가상유형을 비교 분석한 결과를 종합해보면, 현재의 스타일 투자 실태는 펀드명칭에서 표방한 스타일의 일관성을 추구하는 방향으로, 분산투자의 중요성이 더욱 강조되는 방향으로, 시장에 존재하지 않는 스타일이 추가되거나 편중된 스타일이 다양화되는 방향으로 개선될 여지가 있다고 판단된다.

\section{4. 결론 및 시사점}

주식들의 고유한 속성을 파악하여 특정한 스타일 유형으로 구분하고, 스타일 유형 단위 에서 주식을 매매하는 스타일 투자는 선택의 문제를 단순화하고, 포트폴리오 매니저의 성과 평가를 위한 비교집단(peer group)을 생성해 준다는 점에서 실무적으로 매우 유용하다. 
한국증권학회지 제 50 권 2호 (2021)

이러한 스타일 투자의 개념이 해외에서는 업계 및 학계를 막론하고 널리 이용되고 있지만, 우리나라의 경우 업계에서 펀드데이터를 가장 전문적으로 활용하는 펀드평가사에서도 가치형, 성장형 같은 기본적인 스타일 유형 분류조차 제공하지 않을 정도로 시장전반에서 체계적으로 이용되지 못하는 실정이다. 또한 학계에서는 대부분의 선행연구들이 펀드의 스타일을 식별하고, 특정 스타일 유형 펀드들의 성과특성을 파악하려는 스타일 분석(Style Analysis)을 수행함에 있어, 포트폴리오 내역 정보를 활용하지 않고 수익률 정보만을 이용하는 수익률 기반 스타일 분석(RBSA) 방법론을 채택함으로써 특정시점의 스타일을 정확하게 파악하기 어렵고 스타일의 변동을 빠르게 인식하기 못한다는 한계점을 가졌다. 이러한 배경하에서, 이 연구는 특정 시점의 포트폴리오를 직접 관찰함으로써 투자 스타일 및 스타일의 변동을 신속하고 정확하게 파악할 수 있는 포트폴리오 기반 스타일 분석(PBSA) 방법론을 채택하고, 2009년 1월부터 2018년 12월까지 우리나라의 주식형 공모펀드 데이터를 이용하여 스타일 투자 실태를 파악하는 것을 목표로 하였다. 이 연구의 주요결과와 시사점은 아래와 같다.

\section{1 주요결과 요약}

\section{1 .1 스타일 유형 현황}

펀드명칭에 특정단어 포함여부를 바탕으로 구분한 스타일 유형분류에 따르면 2018년 말 기준으로 액티브 펀드의 시장점유율은 가치형(12.4\%), 배당형(10.8\%), 성장형(2.6\%), 중소형 $(4.9 \%)$, 테마형(4.0\%), 사회적책임투자형 $(0.4 \%)$ 순이다. 전반적으로 스타일의 다양성이 결여되고 가치주와 고배당주 스타일로 쏠림현상이 존재하고 있다. 또한 2009년 말에 11.9\%에 불과하던 패시브 펀드의 점유율이 $\mathrm{ETF}$ 의 인기로 인하여 2018년 말에는 $55 \%$ 수준으로 성장하여, 액티브 펀드 선호현상이 사라지고 패시브 펀드 중심의 시장으로 재편되는 모습이다. 한편, 액티브 펀드 중에서도 특별한 스타일을 펀드명칭에 표방하지 않은 일반주식형의 점유율 감소가 가장 두드러지게 나타났다.

\subsection{2 유형별 스타일 측정결과}

포트폴리오 내에 포함된 종목 수는 액티브 펀드 60 개, 패시브 펀드 115 개로 큰 차이를 보였다. 액티브 펀드 중 종목수가 많은 스타일 유형은 중소형(67개), 배당형(66개), 가치형 (63개)이며 종목수가 적은 스타일 유형은 테마형(40개), 대형(32개)이다. 종목집중도는 액티브 펀드 0.046 , 패시브 펀드 0.071 로 종목수와 상반된 결과를 보였다. 보유종목수가 많더라도 시가총액이 큰 종목에 집중하여 투자한다면, 종목집중도는 오히려 커질 수 있음을 말해준다. 액티브 펀드 중에서 종목집중도가 높은 유형은 대형(0.084), 테마형(0.061)이며, 낮은 유형은 배당형(0.036), 중소형(0.028)이다. 산업집중도는 특정 산업의 움직임을 지수화하여 추종 하는 경우가 많은 기타지수ETF형(0.470)에서 두드러지게 높게 측정되었다. 기타지수 ETF형을 제외하고 테마형(0.294)이 산업수준에서 가장 집중된 투자를, 배당형(0.164)은 가장 분산된 투자를 하고 있었다. 보유종목의 가중평균 시가총액은 액티브 펀드 34.7 조 원, 패시브 펀드 
A Study on the Style Investment of Equity Funds

38.8 조 원이다. 시가총액이 가장 큰 유형은 코스피200ETF형(55.9조 원)이며, 가장 작은 유형은 중소형(11.7조 원)이다. 보유종목의 가중평균 장부가-시가 비율은 전체 시장에서 0.801 수준이며, 가치형(0.863)과 배당형(0.880)은 비슷한 값을 나타냈다. 장부가-시가 비율이 가장 낮은 유형은 흥미롭게도 성장형이 아니었다. 성장형(0.771)은 테마형(0.738)보다 측정 값이 높았으며, 특정한 스타일을 표방하지 않는 일반주식형(0.776)과 비슷한 수준을 나타냈다. 보유종목의 가중평균 배당수익률은 전체 시장에서 $1.29 \%$ 수준이며, 가장 높은 유형은 배당형 (1.68\%)이고, 가장 낮은 유형은 테마형(1.11\%)이다. 보유종목을 대상으로 직전 1개월을 제외한 과거 12 개월 수익률을 가중평균한 모멘텀은 전체 시장에서 $20.96 \%$ 수준이며, 액티브 (23.38\%)와 패시브(14.10\%) 간 차이가 무려 9.28\% 정도로 액티브 펀드는 승자주(winner)를 선호하는 경향이 있었다. 모멘텀 측정값이 가장 높은 유형은 중소형(37.65\%)인데, 해당 유형의 성과는 소형주 프리미엄과 승자주 프리미엄이 혼합되어 있음을 말해준다.

\subsection{3 스타일 준수 실태}

앞서 살펴본 스타일 측정결과를 전체 시장 내에서 $0 \%$ 부터 $100 \%$ 까지의 상대순위로 환산하여 해당유형의 시장점유율과 비교하여 보았을 때 괴리가 크게 나타났다. 이는 펀드들이 펀드명칭에서 표방한 스타일을 철저히 준수하지 않음을 말해준다. 이러한 현상이 $\mathrm{Ban}$ and Choe(2013)가 제시한 방치가설(Negligence Hypothesis)과 관련되어 있을 것이라고 가정하고 펀드규모에 따라 스타일 준수 정도가 달라지는지 각 스타일 유형을 펀드규모에 따라 Low, Medium, High그룹으로 나누고 추가적인 검증을 시도하였다. 흥미롭게도 중소형의 시가총액, 가치형 및 성장형의 장부가-시장가 비율, 배당형의 배당수익률, 테마형의 종목수, 종목집중도, 산업집중도 측정값과 상대순위를 보면 펀드규모가 클수록 스타일 특성이 뚜렷하고, 작을수록 특성이 약해지는 경향을 나타내었고, 펀드규모 그룹간 스타일 차이는 통계적으로도 유의 하였다.

\subsection{4 스타일 지속성 검증 결과}

스타일 상대순위를 10 분위 그룹으로 구분한 후, 이번기의 순위(initial ranking)에 따라서 다음기의 순위(subsequent ranking)로 어떻게 변화하는지 조건부 확률(conditional probability)을 계산하였다. 스타일 특성이 가장 뚜렷한 1 분위 및 10 분위 그룹의 스타일 지속 확률을 살펴보면, 승자주(38.2\%) $\rightarrow$ 패자주 $(39.1 \%) \rightarrow$ 저배당주 $(44.8 \%) \rightarrow$ 산업분산(53.5\%) $\rightarrow$ 성장주 $(54.5 \%) \rightarrow$ 고배당주 $(61.3 \%) \rightarrow$ 대형주 $(61.6 \%) \rightarrow$ 종목분산 $(62.2 \%) \rightarrow$ 소형주 $(65.5 \%) \rightarrow$ 종목집중 $(65.6 \%) \rightarrow$ 가치주 $(70.0 \%) \rightarrow$ 소종목 $(70.4 \%) \rightarrow$ 산업집중 $(71.1 \%) \rightarrow$ 다종목 $(73.7 \%)$ 순으로 스타일 지속성이 높았다. 승자주 및 패자주 스타일의 지속성이 가장 낮다는 점은 펀드매니저들이 모멘텀이라는 스타일 속성에 대해 일관된 전략을 구사하지 않고, 타이밍을 하고 있음을 말해주고 있다. 또한 가치주 스타일의 지속성에 비해 성장주 스타일 지속성이 크게 뒤쳐지고 있다. 
한국증권학회지 제 50 권 2호 (2021)

\subsection{5 스타일 타이밍 능력 검증 결과}

Fama-French-Carhart 4요인 모형에 각 요인이 비음(0 또는 +)일 경우에만 해당 요인 값을 부여하는 타이밍 요인을 추가함으로써 스타일 유형별로 적절한 타이밍을 포착하는 스타일 타이밍 능력이 존재하는지 검증하였다. 시장 전체적으로 시장요인, 규모요인에 대한 스타일 타이밍 능력은 관찰되지 않았다. 가치요인에 대한 타이밍 능력은 오직 코스피200 $\mathrm{ETF}$ 형에서만 유의하게 도출되었다. 해당 유형이 시장상황에 따라 가치요인에 대한 노출도를 조절하는 타이밍을 통해 일정부분 성과를 달성했음 말해준다. 모멘텀 요인에 대한 타이밍 능력은 전체시장 및 액티브 펀드 전체집합에서 유의하게 관찰되고 있으며, 액티브 펀드 중에서는 가치형, 배당형, 사회적책임투자형, 테마형, 일반주식형에서 유의하다. 해당유형 에서 모멘텀(추세추종) 전략 또는 역모멘텀(추세역추종) 전략을 구사함에 있어 시장상황에 따라 모멘텀 요인에 대한 노출도를 조절하는 타이밍 전략이 유효했음을 의미한다.

\subsection{6 실제유형 대 가상유형 비교 결과}

펀드명칭을 기반으로 분류한 실제유형에 더하여, 스타일 특성을 뚜렷하게 유지하는 일관된 투자전략을 구사하였다면 성과가 어떠했을 지를 살펴볼 수 있도록 스타일 상대순위를 기반으로 스타일 특성이 가장 뚜렷한 1분위(하위 10\%) 및 10분위(상위 10\%)를 각각 Bottom 및 Top 이라는 가상의 펀드 유형으로 정의하였다.

\subsubsection{1 유형간 상관계수}

액티브 펀드 중에서 가장 높은 시장 점유율을 보인 가치형 및 배당형은 상관계수가 0.993에 달할 정도로 비슷한 스타일이었으며 두 유형과 대응되는 가상유형의 '장부가-시장가 비율 Top' 및 ‘배당수익률 Top' 간의 상관계수도 0.987 로 큰 차이를 보이지 않았다. 분산 투자효과 측면에서 두 유형의 펀드를 각각 보유할 때 실익이 크지 않음을 알 수 있다. 펀드 명칭에서 서로 반대되는 스타일을 표방하는 가치형 및 성장형 간의 상관계수는 무려 0.989 로 표방하는 바와는 다르게 스타일 차별성이 낮음을 말해준다. 흥미롭게도 가치형 및 성장형과 대응되는 가상유형의 ‘장부가-시장가 비율 Top' 및 ‘장부가-시장가 비율 Bottom'유형 간의 상관계수는 0.876 으로 펀드들이 스타일을 준수하였더라면 상관계수가 상당히 감소할 수 있음을 말해준다. 가장 낮은 상관계수(0.743)는 실제유형인 코스피200ETF형 및 중소형 간에서 도출되었다. 현재 시장에서 가장 점유율이 높은 코스피 $200 \mathrm{ETF}$ 는 대형주 위주로 포트폴리오가 구성되는 약점이 있기 때문에 분산투자효과 측면에서 중소형 주식에 투자하는 유형의 펀드가 이러한 약점을 보완할 수 있음을 말해준다.

\subsubsection{2 유형별 보수 및 수수료}

실제유형에서 총보수가 가장 저렴한 유형은 코스피 $200 \mathrm{ETF}$ 형으로 액티브 펀드 평균치인 $1.50 \%$ 의 $1 / 10$ 에도 못 미치는 $0.14 \%$ 에 불과했다. 액티브 펀드로 구분된 8 개 유형의 총보수는 $1.42 \sim 1.62 \%$ 정도로 유형 간에는 총보수의 차이는 크지 않았다. 수수료가 가장 높은 유형은 


\section{A Study on the Style Investment of Equity Funds}

중소형(0.36\%)이었다. 수수료는 펀드환매를 억제하고 장기투자를 유도하기 위한 일회성 비용임을 감안할 때, 유동성충격에 취약한 중소형 유형의 펀드들이 갖은 매매로 인한 유동성 충격비용을 감소시키고자 수수료를 높게 부과하는 것으로 보인다. 가상유형에서 총보수가 가장 높은 유형은 ‘모멤텀 Top'(1.40\%) 유형이었다. 높은 보수를 부과한 액티브 펀드들이 모멘텀 전략을 활발하게 구사함을 말해준다.

\subsubsection{3 유형별 4요인모형 분석}

중소형에서 규모요인, 모멘텀요인에 대한 요인계수의 유의성이 매우 높게 나타났다. 중소형주 투자를 표방한 펀드들이 중소형주 스타일뿐만 아니라 모멘텀 스타일을 동시에 추구했음을 말해준다. 중소형과 대응되는 가상유형의 ‘규모 Bottom' 유형에서는 모멘텀요인에 대한 요인계수가 $1 / 3$ 로 수준으로 감소하였다. 가치형에서는 흥미롭게도 가치요인에 대한 유의성이 가장 낮고, 오히려 규모요인 및 모멘텀요인에 대한 유의성이 더 높았다. 가치주 투자를 표방한 펀드들이 중소형주 및 모멘텀 스타일을 동시에 추구했음을 말해준다. 가치형과와 대응되는 가상유형의 '장부가-시장가 비율 Top'에서는 가치요인에 대한 요인계수 및 유의성의 모두 3 배 정도 증가하였고, 모멘텀요인에 대한 유의성은 사라지고 있다. 가치주 투자를 표방한 펀드들이 가치주 스타일 성향을 더욱 뚜렷하게 증가시킬 수 있는 여지가 있음을 말해준다. 성장형에서는 흥미롭게도 가치요인에 대한 유의성의 없었고, 모멘텀요인에 대해서만 유의성이 높았다. 성장주 투자를 표방한 펀드들이 실제로는 모멘텀 스타일의 주식에 투자하고 있음을 말해준다. 성장형과 대응되는 가상유형의 '장부가-시장가 비율 Bottom' 가치요인에 대한 요인계수가 음(-)이면서 강한 유의성을 나타냈다. 순수익률로 계산한 위험 조정성과는 액티브펀드, 패시브펀드에서 년간 $-1.8 \%,-0.48 \%$ 수준이었으며 이러한 저성과는 대부분 펀드보수에서 기인하였다. 특히, 코스피 $200 \mathrm{ETF}$ 형은 펀드보수가 가장 저렴할 뿐만 아니라 초과성과 창출 측면에서도 가장 우수한 유형인 것으로 나타났다.

\subsubsection{4 유형별 성과}

실제유형과 가상유형의 성과를 비교하였을 때, 실제유형의 위험이 전반적으로 높게 나타났다. 실제유형의 위험이 높으면서, 수익률 또한 저조하여 가상유형이 실제유형을 지배 (dominate)하는 경우가 관찰되었다. '장부가-시장가 비율 Top'은 가치형에 비해 위험은 작고 수익률은 오히려 높았다. 가치주 스타일을 일관되게 추구하였다면 펀드의 성과가 더욱 개선될 수 있었는데 실제현실에서는 스타일이 지속되지 못했음을 말해준다. 실제유형 중 샤프지수 측면에서 가장 성과가 저조했던 기타지수ETF형, 사회적책임투자형, 테마형, 기타 지수인덱스형은 ‘종목수 Top', ‘종목집중도 Bottom', ‘산업집중도 Bottom'에 의해 지배당 하고 있다. 단순하게 분산투자(많은 보유종목수, 낮은 종목집중도, 낮은 산업집중도)만 유지 하더라도 펀드시장의 여러 실제유형보다 우월한 성과를 낼 수 있다는 사실은 분산투자의 중요성을 새삼 깨닫게 해준다. '모멘텀 Top 유형'은 가상유형 중 유일하게 모든 실제유형을 
한국증권학회지 제 50 권 2호 (2021)

지배하고 있다. 뚜렷한 승자주 스타일을 일관되게 유지하는 단순한 투자전략만으로도 우월한 성과를 낼 수 있었다는 사실은 앞으로 모멘텀(추세추종) 전략을 추구하는 스타일 유형이 펀드시장에 새롭게 출현하여 투자자들에게 더 많은 선택지를 제공할 수 있음을 말해준다.

\section{2 시사점 및 제언}

\subsection{1 스타일의 다양성 확보}

이 연구의 분석결과에 의하면 공모 주식형 액티브 펀드 시장은 가치형, 배당형으로 스타일 투자가 편중되어 있음을 알 수 있었다. 두 유형의 상관계수는 0.993으로 매우 높은 값을 보여 사실상 액티브 펀드 시장이 거의 한 가지 유형으로 쏠림된 구조를 가지고 있다 해도 과언이 아니다. 다행히도 과거 10년간 가치주, 배당주가 성과가 좋았지만, 성장주가 주도 하는 장세, 배당주의 성과가 저조한 장세에서 편중된 스타일 투자는 저조한 성과를 산출 하게 될 것이다.

또한, 유형별 장부가-시장가 비율을 측정한 결과, 가치형은 스타일 상대순위가 $62 \%$ 에 불과하였는데 이는 명확한 가치주 스타일이 아니라, 가치형과 혼합형(Blend)의 경계선 상에 있는 스타일이기 때문에 스타일을 좀더 가치형으로 변화시킬 수 있는 여지가 존재한다. 성장형은 스타일 상대순위가 $46 \%$ 수준으로 성장주 성향이 거의 없고 혼합형 스타일에 가깝다. 현 상태의 성장형 펀드들을 제대로 된 성장형으로 변화시킬 수 있는 여지가 많다고 할 수 있다.

중소형에 비하여 대형은 제대로 된 분석을 할 수 없을 정도로 펀드개수가 작고 시장점 유율은 지극히 미미하였다. 시가총액 상위 200개의 성과를 추종하는 패시브 펀드(KOSPI200 ETF 및 KOSPI200 Index) 유형의 인기로 인해 액티브 대형주 펀드에 대한 투자자들의 수요와 운용업계의 공급이 모두 부족한 것으로 판단된다. 운용업계에서는 상위 100 개 주식, 상위 50개 주식 등 패시브 펀드 보다 대형주 스타일이 뚜렷한 액티브 펀드로 차별화하여 펀드 상품의 다양성을 제고하는 전략이 필요해 보인다.

\subsection{2 액티브 및 패시브 스타일 간 조화와 균형}

공모펀드 시장은 최근 10 년간 액티브 펀드 위주에서 패시브 펀드 중심으로 시장의 성격이 확연하게 바뀌고 있다. 시장 참여자들 사이에서 장기적으로 저비용-고효율의 패시브 전략을 핵심(Core)으로 유지하고, 액티브 전략을 위성(Satelite)으로 활용하는 것이 바람직하다는 점에 대한 공감대가 형성되어가고 있음을 시사한다. 다만, 스타일 간 조화와 균형을 위해서는 핵심전략의 약점을 위성전략이 보완하여 시너지를 창출하는 방향으로 나아가야 할 것으로 판단된다. 우리나라의 공모형 패시브 펀드가 대체로 KOSPI200 지수를 추종하는 까닭에 스타일 특성들이 중립적(neutral)이지 못하고 특정한 방향으로 쏠릴 가능성이 존재하는 것이다. 실제로 KOSPI200ETF 및 KOSPI200 Index 유형 펀드들의 포트폴리오는 비교적 높은 종목집중도, 대형주 성향, 역모멘텀 성향을 나타내고 있다. 따라서, 종목집중도가 낮고, 
A Study on the Style Investment of Equity Funds

중소형주 성향이 강하고, 모멘텀 성향이 강한 액티브 펀드들이 이러한 패시브 펀드들의 약점을 보완할 수 있을 것이다.

또한, 패시브 펀드 추종지수를 KOSPI200 중심에서 벗어나 다변화할 필요가 있다. 예를 들면, 비교적 최근에 출시된 KRX300 지수는 KOSPI200에서 대형주 비중을 5\%이상 감소 시키고, 이를 중형주와 소형주로 채운 지수인데, 추종지수를 다변화하는데 출발점이 될 수 있을 것으로 기대한다. 또한 유가증권시장 전체를 추종하는 KOSPI지수, 유가증권시장과 코스닥시장의 전체집합을 추종하는 통합지수(KOSPI+ KOSDAQ) 유형을 추가하는 것도 현재의 패시브 펀드 유형의 약점을 보완하는데 도움을 줄 수 있을 것이다.

\subsection{3 스타일 유형 분류 현실화 및 적절한 벤치마크 사용}

우리나라에서 펀드데이터를 가장 전문적으로 활용하는 펀드평가사에서도 가치주, 성장주 같은 기본적인 스타일 유형 분류조차 제공하지 못하고 있는 실정이다. 예를 들면, 펀드 명칭 에서 특정단어를 검색하여 분류하는 단순한 방법을 사용하더라도 2018년 말 현재 가치형 및 성장형은 전체 액티브 펀드 중 $1 / 3$ 을 차지할 정도로 흔한 스타일 유형임에도 제로인에서는 해당 유형의 펀드 대부분을 스타일 특색이 없는 일반주식 유형으로 분류하고 있으며, 일부는 중소형, 배당형, 테마형으로 분류하고 있다.

Barberis and Shleifer(2003)는 스타일 투자의 장점으로 스타일별 비교집단(peer group)이 자동적으로 생성되어 포트폴리오 매니저의 성과를 평가하기가 용이하다는 점을 꼽고 있는데, 성과를 제대로 평가하기 위해서는 현실적인 스타일 유형 분류와 함께 적절한 벤치마크 사용이 요구된다. 가치형, 성장형으로 분류되는 펀드들을 평가할 수 있도록 적절한 가치주지수, 성장주지수 도입이 필수적이라 하겠다. 또한, 현재 제로인에서 중소형주 유형 평가에 사용 하는 벤치마크인 KOSPI200 중소형지수는 KOSPI200 구성종목 중 시가총액이 상위 100 종목을 제외한 나머지 종목을 대상으로 산출하는데, 지나치게 대형주를 대표하는 측면이 있다. 시가총액 200위를 벗어난 중소형주에 주력으로 투자하는 펀드들을 평가하기 위해서는 대안적인 벤치마크 지수 도입이 필요하다. 배당주 유형 평가에 사용하고 있는 KOSPI 고배당 50 지수는 유가증권시장에서 배당수익률이 높은 50종목으로만 산출하는데, 이 연구에서 배당 형으로 분류한 펀드들의 포트폴리오를 분석하면 평균적인 보유종목수는 66개에 달하였다. 보다 현실성 있는 벤치마크 지수가 필요함을 시사한다.

\subsection{4 스타일 모니터링 체계 도입}

펀드들이 펀드명칭에서 표방한 스타일을 철저히 준수하지 않는 경향이 있으며, 펀드규모가 클수록 스타일 특성이 뚜렷하고, 작을수록 특성이 약해진다는 사실은 운용업계가 소규모 펀드를 소홀히 취급하면서 신인의무(fiduciary duty)를 다하지 않음을 시사하고 있다. 투자자 보호를 위해 펀드 포트폴리오 정보를 보유한 금융투자협회 및 펀드평가사가 주축이 되어 펀드의 스타일을 모니터링 할 수 있는 체계를 도입할 것을 제안한다. 펀드평가사에서 모닝 
한국증권학회지 제 50 권 2호 (2021)

스타의 스타일 박스(Style Box)와 같은 간단한 도구를 우리나라 펀드시장에 맞게 적용하여 보는 것도 모니터링 체계에 대한 좋은 출발점이 될 수 있을 것이다.

스타일 모니터링에 대한 필요는 일반투자자에게 국한되는 것은 아니다. 연기금 등에서 운용업계에 펀드운용을 위탁할 때에도 스타일 유형을 설정하고 해당유형에 맞는 운용지침 (mandate)을 부여하는 것에 더하여, 스타일을 준수하는지에 대한 체계적인 모니터링을 위해 포트폴리오 정보를 신속하게 공유해야 할 것이며, 스타일 특성이 운용지침에서 벗어 나는지 즉각적으로 판단할 수 있는 시스템을 갖추어야 할 것으로 판단된다.

\subsection{5 펀드투자자를 위한 시사점 및 제언}

스타일 모니터링 체계가 미흡한 상황에서, 펀드투자자들은 펀드명칭에서 표방하는 스타일을 전적으로 신뢰하기보다 비판적으로 수용할 필요가 있으며, 정확한 스타일을 파악하는 것은 어렵더라도 자산운용보고서를 통한 최소한의 점검은 필요하다고 판단된다. 현행 자본시장법 제88조에서는 자산운용사가 3 개월마다 1 회 이상 자산운용보고서를 투자자에게 교부하고, 동법 시행령 제92조에서는 투자대상 중 상위 10개 종목을 기재하도록 강제하고 있다. Korea Financial Investors Protection Foundation(2019)에 따르면 대략 42\%의 투자자만 자산 운용보고서를 읽어본다고 한다. 더 많은 투자자들이 자산운용보고서에 관심을 가지고 포트 폴리오 내역을 주기적으로 확인하고 투자자가 원하는 스타일 특성에 부합하는지 점검할 필요가 있다.

한편 투자자들은 소규모펀드일수록 스타일 특성이 약해진다는 점을 주목할 필요가 있다. 소규모펀드는 직설적으로 표현하자면 인기 없는 펀드, 마케팅에 실패한 펀드이며 작은 수탁고로 인해 운용사의 전체수익에 대한 기여도가 미미한 펀드라고 할 수 있다. 지나치게 많은 펀드들이 출현하고 빠르게 사라지는 우리나라 펀드시장의 특성을 감안할 때, 운용사가 이러한 소규모펀드에 대해 명칭에서 표방한 스타일을 준수하면서 정성 들여 운용하리라고 기대하기 어렵다. 투자자 입장에서 소규모펀드는 가급적 피해야 할 것이다.

또한 투자자들이 ETF에 관심을 가지고 핵심(Core) 포트폴리오를 구축하는데 적극 활용할 필요가 있다. 펀드시장에서 가장 인기를 끌고 있는 코스피200ETF유형은 총보수가 액티브 펀드 평균치의 $1 / 10$ 에도 못 미치는 저비용의 이점을 가질 뿐만 아니라 초과성과 창출 측면 에서도 운용능력이 가장 우수한 것으로 분석되었기 때문이다. 다만, 코스피 $200 \mathrm{ETF}$ 유형이 대형주 및 역모멘텀 스타일 성향을 나타내기 때문에 이러한 점을 보완하기 위해 중소형주 및 모멘텀 스타일 성향 펀드들을 위성(Satelite) 포트폴리오로 활용해 볼 것을 제언한다. 


\section{References}

Ban, J., 2015, Effects of Sales Expenses and Management Expenses on Mutual Fund Performance and Flows, Asia-Pacific Journal of Financial Studies, Vol. 44, pp. 129-173.

Ban, J., S. Kim, and S. Kwon, 2016, Performance Characteristics of KOSPI200 Index Funds, Korean Journal Financial Studies, Vol. 45, pp. 1035-1074.

Ban, J., and H. Choe, 2013, Fund Size and Performance in a Market Crowded with Many Small Funds, Asia-Pacific Journal of Financial Studies, Vol. 42, pp. 340-372.

Barberis, N., and A. Shleifer, 2003, Style Investing, Journal of Financial Economics, Vol. 68, pp. 161-199.

Bogle, J. ed., The Little Book of Common Sense Investing, John Wiley \& Sons, Inc., New Jersey, 2007.

Carhart, M. M., 1997, On Persistence in Mutual Fund Performance, The Journal of Finance, Vol. 52, pp. 57-82.

Chan, L. K. C., H. L. Chen, and J. Lakonishok, 2002, On Mutual Fund Investment Styles, The Review of Financial Studies, Vol. 15, pp. 1407-1437.

Chan, H. W. H., R. W. Faff, D. R. Gallagher, and A. Looi, 2009, Fund Size, Transaction Costs and Performance: Size Matters!, Australian Journal of Management, Vol. 34, pp. 73-96.

Chen, J., H. Harrison, M. Huang, and J. D. Kubik, 2004, Does Fund Size Erode Mutual Fund Performance? The Role of Liquidity and Organization, American Economic Review, Vol. 94, pp. 1276-1302.

Cho, E., J. Ban, H. Choi, and E. Tae, A Study on Style Investment: Implication for the Active External Management of the National Pension Fund, Research Report, National Pension Research Institute, 2020, Available from: http://institute.nps.or.kr/jsppage/res earch/resources/resources_04.jsp.

Evans, R. B., 2010, Mutual Fund Incubation, Journal of Finance, Vol. 65, pp. 1581-1611.

Fama, E. F., and K. R. French, Why Active Investing is a Negative Sum Game, Fama/French Forum Essays, 2009, http://www.dimensional.com.

Fama, E. F., and K. R. French, 1993, Common Risk Factors in the Returns on Stocks and Bonds, Journal of Financial Economics, Vol. 33, pp. 3-56.

Fama, E. F., and K. R. French, 2010, Luck Versus Skill in the Cross-Section of Mutual Fund Returns, Journal of Finance, Vol. 65, pp. 1915-1947.

Ha, Y., 2015, A Comparative Study on Investment Style and Performance of Domestic Equity Funds: Focusing on Public Offering and Private Funds, International Area Studies Review, Vol. 19, pp. 63-76.

Henriksson, R. D., and R. C. Merton, 1981, On Market Timing and Investment Performance. 
한국증권학회지 제 50 권 2호 (2021)

II. Statistical Procedures for Evaluating Forecasting Skills, Journal of Business, Vol. 54, pp. 513-533.

Investment Company Institute, Investment Company Fact Book $59^{\text {th }}$ edition: A Review of Trends and Activity in the Investment Company Industry, Investment Company Institute, Washington D.C., 2019.

Jegadeesh, N., and S. Titman, 1993, Returns to Buying Winners and Selling Losers: Implications for Stock Market Efficiency, Journal of Finance, Vol. 48, pp. 65-91.

Kacperczyk, M., C. Sialm, and L. U. Zheng, 2005, On the Industry Concentration of Actively Managed Equity Mutual Funds, Journal of Finance, Vol. 60, pp. 1983-2011.

Kang, J. K., and C. J. Lee, 2010, Investment Styles and Performance Persistence of Equity Funds in Korea Using Sharpe's Style Analysis, Korean Journal of Financial Studies, Vol. 39, pp. 307-339.

Kho, B. C., U. Chang, and Y. Choi, 2011, Style Analysis and its Application of Domestic Mutual Funds, Korean Journal of Futures and Options, Vol. 19, pp. 91-120.

Kim, D. C., and S. I. Yoo, 2013, Style, Intertemporal, and Cross-Sectional Analysis of Equity Mutual Funds in Korea, Korean Journal of Financial Studies, Vol. 42, pp. 585-617.

Kim, D. S., K. H. Lee, and H. D. Kim, 2019, An Empirical Study on Size and Age Effects in Korean Equity Funds: Focusing on the Issue of Neglected Funds, Korean Journal Financial Studies, Vol. 48, pp. 641-673.

Korea Financial Investors Protection Foundation, 2018 Fund Investors Survey, 2019.

Kwon, I., and S. Song, 2010, Verification of the Style Consistency of Domestic Equity Mutual Funds Using Return-Based Style Analysis, Korean Journal of Applied Statistics, Vol. 23, pp. 783-797.

Lee, C., and H. Jeon, 2012, On the Investigation of Investment Style Consistency in Korea Equity Funds, Korean Journal of Financial Management, Vol. 29, pp. 83-106.

Morey, M. R., 2003, Should You Carry the Load? A Comprehensive Analysis of Load and No-Load Mutual Fund Out-of-Sample Performance, Journal of Banking \& Finance, Vol. 27, pp. 1245-1271.

Pollet, J. M., and M. Wilson, 2008, How Does Size Affect Mutual Fund Behavior?, Journal of Finance, Vol. 63, pp. 2941-2969.

Sharpe, W. F., 1991, The Arithmetic of Active Management, Financial Analysts Journal, Vol. 47, pp. 7-9.

Sharpe, W. F., 1992, Asset Allocation: Management Style and Performance Measurement, Journal of Portfolio Management, Vol. 18, pp. 7-19.

Yoo, S. I., and D. C. Kim, 2012, Style, Performance, Market Timing of Equity Mutual Funds in Korea, Asian Review of Financial Research, Vol. 25, pp. 409-450. 